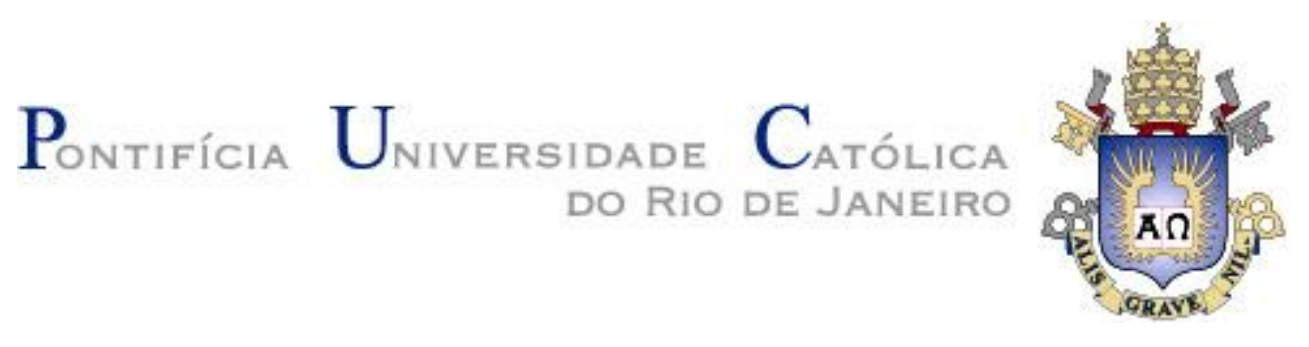

Jaqueline Cavalcante Correia

\title{
Apaches no Rio: crime, carnaval e gênero na Capital Federal
}

(1912-1915)

Monografia apresentada à Graduação em História da PUC-Rio como requisito parcial para obtenção do título de licenciatura em História.

Orientador: Prof. Diego Antonio Galeano

Rio de Janeiro, dezembro de 2017 


\section{Agradecimentos}

Agradeço a todos que me encorajaram, me apoiaram ao longo da minha graduação e acreditaram, assim como eu, que recomeçar é sempre possível. Agradeço, também, ao professor Diego Antonio Galeano pela orientação e ao professor Rômulo Costa Mattos pela leitura crítica. 


\section{Resumo:}

Na primeira década do século $X X$, a polícia parisiense iniciou uma intensa perseguição a grupos de jovens criminosos que atuavam no centro de Paris. Conhecidos como "apaches", a partir desse momento resolveram migrar a outras cidades da Europa, chegando inclusive até os portos do espaço Atlântico sul-americano, como Buenos Aires e Rio de Janeiro. Esta monografia analisa as dimensões materiais e simbólicas desse fenômeno cultural, com particular foco no impacto que teve a deportação de apaches de Buenos Aires, e seu passo pelo Rio de Janeiro, na década de 1910.

\section{Palavras-chave:}

Apaches parisienses - Rio de Janeiro - Século XX - Crimes 


\section{Sumário}

$\begin{array}{ll}\text { Agradecimento } & 02\end{array}$

$\begin{array}{ll}\text { Resumo } & 03\end{array}$

$\begin{array}{ll}\text { Lista de imagens } & 05\end{array}$

$\begin{array}{ll}\text { Introdução } & 06\end{array}$

Capítulo I - A invenção dos apaches: de Paris a Barcelona 10

1.1 A criação do "apachismo" em Paris 10

1.20 chicote como forma de punição aos apaches 17

1.3 Apaches na Espanha

21

Capítulo 2 - Apaches vindos de Buenos Aires 25

2.1 A repressão policial 25

2.20 jornalismo investigativo 30

2.3 O crime de lenocínio 35

Capítulo 3 - Apaches e gigolletes no Carnaval do Rio de Janeiro de 1915

3.1 Blocos e fantasias $\quad 42$

3.2 A questão de gênero no carnaval de 1915: a presença da mulher no espaço público $\quad 51$

$\begin{array}{ll}\text { Conclusão } & 59\end{array}$

Fontes $\quad 62$

$\begin{array}{ll}\text { Bibliografia } & 64\end{array}$ 


\section{Listas de imagens}

1. Técnica frequente para roubo dos apaches 12

2. L'apache est la plaine de Paris 13

3. Imprudents apaches 13

4. Armas de apaches 14

5. Chicote nas prisões inglesas 18

6. Cavaletes para castigos corporais 18

7. Apaches em Madrid 22

8. Charge alusiva a entrada de apaches no Brasil 26

9. Pablo Hollande, José Rochet, Maurício Zico e Pablo Luiz 28

10. Miguel Luz, Carlo Bouchet e Antoine Lemousin 29

11. Telegrama da polícia de Buenos Aires enviado à polícia carioca 31

12. Redongo Vega e Carmem Martinez 37

13. "Saída do cárcere" 1 e 2, de Herman Parl 38

14. Cena final da burleta em 1 ato, Apaches em casa, Teatro Trianon 39

15. "Último bando" 41

16. Charge "Casal de apache" no carnaval carioca 44

17. Menina Irene Silva, fantasiada de apache 45

18. Grupo de empregados do comércio local, com suas famílias 47

19. Luiz Moreira e Maria Helena caracterizados de apaches no Carnaval 49

20. Grupo de senhores e senhoras caracterizado de apaches 49 


\section{Introdução}

$\mathrm{Na}$ primeira década do século $\mathrm{XX}$, a polícia francesa iniciou uma intensa repressão contra grupos de bandidos que atuavam no centro de Paris. Eles eram conhecidos como apaches e, aos poucos, foram se tornando "os bárbaros" mais temíveis - roubavam, matavam, saqueavam descarada e ferozmente. Todos os dias, os principais jornais de Paris, como o Le Journal e o Le Matin, noticiavam seus delitos e usavam a rubrica "Paris-Apache".

O apache era um "produto" genuinamente francês, mais precisamente da Paris popular, dos bairros de periferia e, segundo Bouyssou, juiz no tribunal do Sena, sob o nome genérico de apaches:

Costuma-se designar há alguns anos todos os indivíduos perigosos, unidos pela reincidência, inimigos da sociedade, sem pátria nem família, desertores de todos os deveres, dispostos aos golpes mais audaciosos, a todos os atentados contra a pessoa ou a propriedade. ${ }^{1}$

Dessa forma, em plena Belle époque, a França viveu o auge do seu "momento apache". E é a esse personagem tão temido e ao mesmo tempo instigante que dedico a minha pesquisa. É importante ressaltar que a dimensão cultural teve início com a imprensa: os jornalistas começaram a utilizar o termo apache para narrar um grupo social de contornos pouco claros. Portanto, foi o uso metafórico da noção de apache que levou os jovens a se identificarem e se reconhecerem como apaches. A construção simbólica desse estereótipo inclui roupas e algumas características. "Recusa do trabalho (...), gosto pela perambulação, pelo fumo, álcool, mulheres, os prazeres do consumo e sobretudo das roupas. O Apache gosta de estar bem arrumado sem ser burguês". ${ }^{2}$

$\mathrm{Na}$ França, o "fenômeno apache" inspirou a literatura folhetinesca, na Espanha fomentou a imprensa sensacionalista, na América do Sul, mais precisamente em Buenos Aires e Rio de Janeiro, fomentou não só a imprensa, mas o imaginário das

\footnotetext{
${ }^{1}$ TESTUT, Les Vagabonds mineurs, tese de direito, 1808 apud Perrot, Michelle. Os excluídos da História. Operários, mulheres e prisioneiros. São Paulo: Paz e Terra, 2017, p. 344.

${ }^{2}$ COUSIN, Laurent. Les apaches, Délinquance Juvénile à Paris au début du XX ${ }^{e}$ siècle, dissertação de mestrado de história, Paris, VII-Jussieu, 1976 apud Perrot, Michelle. Os excluídos da História. Operários, mulheres e prisioneiros. São Paulo: Paz e Terra, 2017, p. 346.
} 
representações culturais, como o carnaval carioca de 1915. Dito isto, este trabalho, para dar conta de tais questões, está estruturado em três capítulos.

No primeiro capítulo, faço uma revisão bibliográfica com textos que abordam a invenção dos apaches e sua centralidade na cultura de massa francesa na Belle époque. Dois historiadores franceses de referência que trabalharam com o tema e suas obras ganham destaque neste momento do texto e ao longo de todo o trabalho: Michelle Perrot e Dominique Kalifa. Primeiro, mostro como esses autores trabalharam a origem do termo apache e o tratamento que deram para tal fenômeno de acordo com suas respectivas perspectivas. Em seguida, trato do surgimento de uma juventude operária que resistiu ao rigor estabelecido pelas fábricas e que, aos poucos, foi excluída pela sociedade; eram os jovens desclassificados.

Paralelo a isso, com o aumento da criminalidade entre as faixas etárias de 16 e 21 anos, surge um debate na imprensa, entre policiais, políticos e magistrados a favor da adoção de castigos físicos como punição a esses criminosos. Nesse contexto, analiso também o impacto das políticas repressivas do governo francês, desencadeando a notável migração de sujeitos acusados de apachismo para outras cidades europeias, em particular Barcelona.

Ao tratar dessa migração na Europa, faço uma breve abordagem sobre a presença de apaches em Madrid e trabalho, particularmente, com a obra do historiador espanhol Raúl Gimero de Lo Hoz. Fuera de la Ley. Hampa, Anarquistas, Bandoleiros e Apaches. Los Bajos fondos en España (1900-1923). Analiso como se deu o fenômeno na Espanha, como a imagem do apache foi construída pela imprensa sensacionalista naquele país e tratado como um produto de exportação da França. Investigo, por fim, o momento inicial da Primeira Guerra Mundial e, consequentemente, o desaparecimento paulatino de apaches em solo espanhol.

No segundo capítulo, mostro como essa "diáspora" de apaches, além de envolver outros países da Europa, como a Espanha, teve uma dimensão transatlântica, com particular presença nas rotas migratórias do espaço Atlântico sul-americano. Nesse momento - mais precisamente entre os anos de 1912 e 1913 -, o fenômeno 
“apaches importados” teve grande presença na imprensa, na literatura e na música do Rio da Prata e do Brasil.

Neste capítulo, analiso particularmente uma conjuntura de repressão de imigrantes franceses acusados de apachismo em Buenos Aires e submetidos à lei de expulsão de estrangeiros, sendo muitos deles embarcados com destino a Europa. A obra utilizada como referência é a do historiador Diego Galeano, Criminosos Viajantes. Circulações transacionais entre Rio de Janeiro e Buenos Aires (18901930), principalmente para destacar a figura do "ladrão viajante" e o surgimento do crime internacional facilitado pelas inovações tecnológicas da modernidade.

Mostro como se deu a repressão policial em vista da possibilidade de desembarque desses criminosos (que estavam a bordo dos grandes transatlânticos) no porto do Rio de Janeiro e a colaboração mútua estabelecida entre as autoridades policiais de Buenos Aires e Rio de Janeiro, principalmente através de telegramas. Também é importante e faz parte da minha investigação o papel de jornalistas investigativos, que rastreavam os criminosos em fuga em busca de informações para suas matérias e colaboravam com a polícia através das informações obtidas. Desta forma, também exploro neste trabalho a nova face do jornalismo das últimas décadas do século XIX, representado pelas grandes folhas, de caráter mais comercial, constituindo a grande imprensa do Brasil.

Ainda neste capítulo, abordo o crime de lenocínio, tão associado ao universo apache, e o papel da mulher que ocupa o centro da violência apache. Analiso o significado do termo canfinfleros nesse universo, as construções jornalísticas em torno da imagem dos apaches e a influência do apachismo nas representações teatrais.

Por fim, no terceiro capítulo, reduzo a escala analítica para me concentrar em um episódio concreto, no qual os apaches tiveram grande visibilidade, que foi o carnaval do Rio de Janeiro. Para isso, analiso o carnaval carioca de 1915 e suas representações. Neste momento, a questão de gênero ganha destaque com a investigação acerca da presença da mulher em espaços públicos. A imagem de gigollette era usada nas fantasias de carnaval, reforçando o debate em torno da honra da mulher e da família. 
Para tratar da questão de gênero, trabalho com obras de referência sobre o tema, como as das historiadoras Sueann Caulfield, Maria Clementina Pereira Cunha e Martha de Abreu Esteves, além de trazer para este debate a posição de Viveiro de Castro, jurista que atuou entre o final do século XIX e início do XX.

Minha monografia está baseada principalmente em pesquisa de fontes jornalísticas, material disponível na base de dados da Biblioteca Nacional Hemeroteca Digital, além de fontes iconográficas e da bibliografia citada. As fontes jornalísticas têm um papel preponderante na elaboração do trabalho porque me permitiram ampliar o olhar em relação ao fenômeno do apachismo. Isto porque pude perceber o aspecto sócio-cultural que envolve tal fenômeno, evidente na construção do apachismo pela imprensa e por outras representações culturais, como teatro, música e literatura. As notícias referentes aos apaches publicadas pelos principais jornais da época percorrem principalmente o período entre 1912 e 1913.

Em suma, nas próximas páginas, procuro mostrar que o apachismo nascido na França envolveu muito mais do que crime, morte, prostituição e perseguição. Foi um fenômeno que mobilizou e percorreu a imprensa, a literatura, o cinema, o teatro, a música, as representações sociais da época e, apesar de desaparecer paulatinamente com a repressão policial nas duas primeiras décadas do século $\mathrm{XX}$, continuou a habitar o imaginário social por muito tempo. 


\section{Capítulo 1 - A invenção dos apaches: de Paris a Barcelona}

\subsection{A criação do "apachismo" em Paris}

Na primeira década do século XX, as autoridades policiais, na França, moveram uma intensa campanha, liderada pelo prefeito de polícia, Sr. Lépine, para acabar com o "apachismo" no centro de Paris e os apaches foram alvos de perseguição e morte. Em 21 de dezembro de 1910, o jornal carioca $O$ Paiz publicou uma crônica descrevendo o "fenômeno apache" em Paris:

O apache é a grande nódoa, é a mácula suprema, já não se diga só da civilização francesa, mas da civilização universal. Todos os dias os jornais registram em Paris seus honrosos feitos. Matam, saqueiam, roubam, ferem, descarada e ferozmente. A polícia os persegue a todo o transe, mas não só não logra exterminá-los, como até, por vezes, é por eles trucidada. (...) Paris - porque Paris é seu campo de ação mais vasto e predileto - vai, desse modo, construindo o rubro teatro onde se desenrolam as mais vergonhosas, as mais negras, as mais torpes, as mais bárbaras, as mais sanguinolentas cenas, em que tais bandidos fazem-se protagonistas. ${ }^{3}$

A figura dos apaches suscitou o interesse da imprensa e de diversos historiadores franceses, e num momento de ascensão de uma história social voltada para a compreensão das classes trabalhadoras, o fenômeno virou objeto de atenção. $O$ caso mais notável é da historiadora francesa Michelle Perrot com importante atuação na área da história social ${ }^{4}$ e de forte influência foucaultiana ${ }^{5}$. Seus personagens mais marcantes, operários, mulheres e transgressores da lei, são trabalhados de forma a

\footnotetext{
3 "Os três tiras". O Paiz, Rio de Janeiro, 21 de dezembro de 1910.

4 Michelle Perrot inovou com seu trabalho de historiadora principalmente em duas importantes áreas da história social: a história da classe trabalhadora e a história das mulheres. Sua primeira obra, Les ouvriers en gréve (1974), mostra a relevância e o significado do fenômeno da greve na França no final do século XIX, e a obra Os excluídos da história (1988) abrange uma representativa coletânea de artigos de sua própria autoria, apresentando estudos sobre operários prisioneiros e mulheres. Nos últimos anos seu interesse esteve voltado sobretudo para a história das mulheres, sendo responsável pela organização, juntamente com Georges Duby, da coleção de cinco volumes, Histórias das mulheres (1993).

${ }^{5}$ Como historiadora, M. Perrot defende a importante contribuição de Foucault para a história, principalmente por introduzir certos domínios que eram pouco tratados como a história das prisões na obra "Vigiar e punir" (1977). Segundo ela, foi a partir desse texto que Foucault abriu um verdadeiro campo de pesquisas sobre a história da delinquência, da prisão, das penalidades e das colônias penitenciárias para jovens. Para a autora, esse trabalho de Foucault vai muito além, ao englobar poder, biopolítica e disciplina, permitindo, assim, compreender de outra maneira a história do trabalho e a disciplina operária, ou melhor, compreender por que e como as políticas sociais se desenvolveram em certos momentos e o que significam.
} 
ganhar a dimensão de sujeitos da história. Dessa forma, Michelle Perrot põe em cena em suas obras os "excluídos da história", a importância de cada um desses atores, e as transformações sociais que eles mobilizaram em seu tempo.

Para Perrot, "a paternidade" da transposição do termo apache ainda é muito controversa. Para uns seria fruto de construções da mídia jornalística; para outros, seria resultado de indignação policial; ou ainda, para outros, a palavra seria uma definição dada pelos próprios jovens delinquentes que se reconheciam e reivindicavam para si a imagem índia que era associada ao termo. Isso porque era costume desses jovens nomear seus bandos com nomes coletivos e simbólicos ${ }^{6}$. Dessa forma, em plena Belle époque, a França viveu o auge do seu "momento apache".

Dominique Kalifa, outro historiador francês que se interessou e trabalhou com o tema, lança um olhar para o fenômeno apache na França a partir de uma perspectiva cultural $^{7}$, acrescentando que essa transposição poderia ter sido devido ao entusiasmo do século direcionado à campanha da conquista do Oeste americano pela França, ao exotismo do índio e às transferências que ele mobiliza, destacando que o termo resistiu muito bem, exceto entre o período entreguerras, sendo constantemente reativado pelo cinema, pela música, pela literatura anedótica e o romance policial ${ }^{8}$.

Em Arqueologia do apachismo, Kalifa faz uma periodização detalhada do aparecimento do termo apache na literatura francesa em alusão aos povos da América Setentrional, que inspiraram principalmente o imaginário de Fenimore Cooper em um "primeiro momento índio". Mas, segundo Kalifa, foi Balzac o primeiro a tecer a metáfora entre os índios da América à violência e à periculosidade dos criminosos em Paris no final do século XIX.

\footnotetext{
${ }^{6}$ Perrot, Michelle. Os excluídos da História. Operários, mulheres e prisioneiros. São Paulo: Paz e Terra, 2017, p.343.

${ }^{7}$ Dominique Kalifa, ao tratar o fenômeno apache a partir de uma perspectiva cultural, acaba por se distanciar de Perrot que trata o apachismo como um fenômeno social. No entanto, D. Kalifa considera a história cultural como instrumento de entrada para se fazer história social. Isso porque, para ele, a história social ainda continua sendo o coração da história - "o social como interação dos indivíduos e como produção que uma sociedade pode ter de si própria"; já a história cultural, sendo pensada como história das representações. Com isso, Kalifa sempre se preocupou em cruzar a história das representações e a história das produções sociais.

${ }^{8}$ KALIFA, Dominique. Arqueologia do "Apachismo": Bárbaros e Peles-vermelhas no século XIX. Projeto História, nº40, 2010, p.40.
} 
Aos poucos, autores como Gustave Airmand, foram fazendo associações mais diretas, definindo os apaches de Paris como o último grau de selvageria, e o uso do termo foi progredindo para designar todo indivíduo ameaçador ou fora de norma. Dessa forma, estava traçado o lugar central que o "apache" ocupava nesse sistema de representações: figura inqualificável, arquétipo do selvagem feroz e sanguinário.

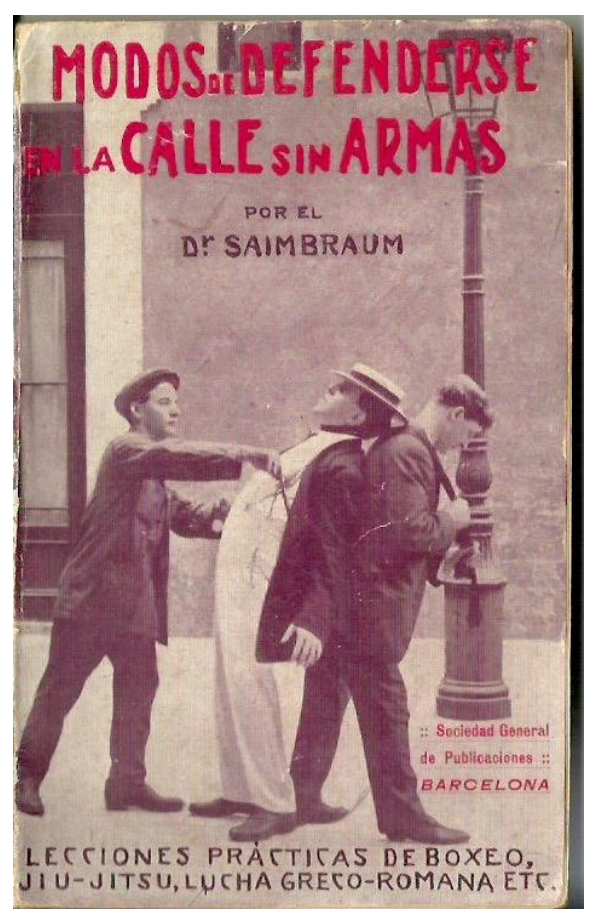

Imagem 1: Técnica frequente para roubos dos apaches ("Modos de defenderse en la calle, sin armas, Dr. Saimbraum, 1914", reproduzido em HOZ: 2016, 510)

A partir de 1907, o termo se tornou comum e generalizado e nas colunas em que o Le Journal ou o Le Matin noticiavam diariamente os delitos praticados pelos apaches, era usada a rubrica "Paris-Apache". Aos poucos, a imprensa parisiense foi construindo a imagem estereotípica do apache: criminoso do centro de Paris, impiedoso, perigoso, que suscitava medo, mas ao mesmo tempo, despertava fascinação, atração e interesse dos leitores.

No Brasil, a imprensa, na segunda década do século $\mathrm{XX}$, aos poucos vai seguindo os passos da imprensa parisiense, publicando os feitos dos apaches de Paris e, ao mesmo tempo, tomando de empréstimo o termo para designar criminosos vindos 
de "fora" ou melhor, "criminosos viajantes", como define Diego Galeano. Trataremos deste assunto mais adiante.
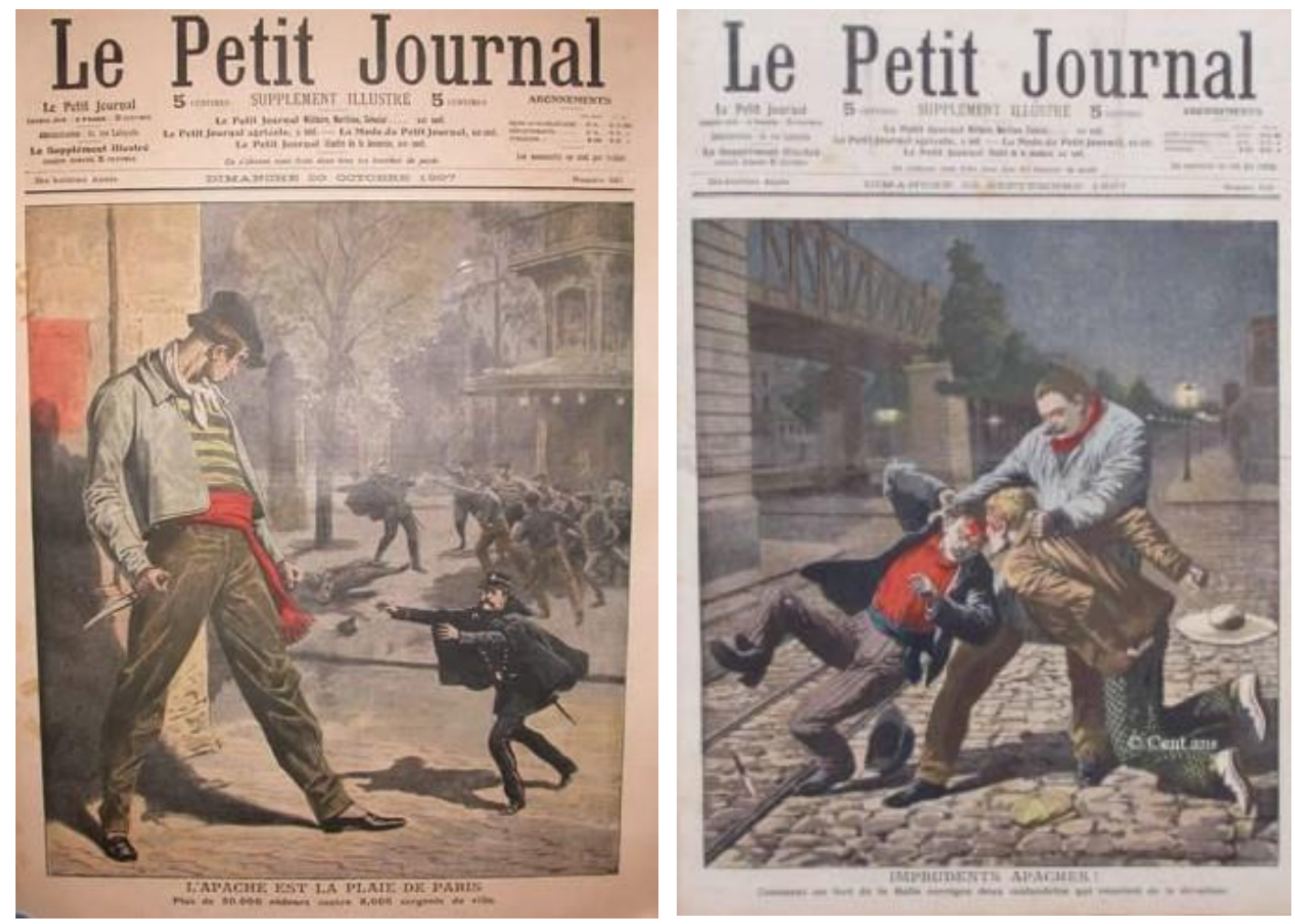

Imagem 2: Le Petit Journal, Paris, 20 de outubro de 1907 Imagem 3: Le Petit Journal,Paris, 12 de setembro de 1907

Afinal, quem eram os apaches? Segundo Perrot, eles eram os últimos rebeldes que resistiam à disciplina industrial, cristalizaram um medo latente e, ao mesmo tempo, despertaram a admiração e inveja de uma parcela da juventude das classes populares que tentavam se identificar com eles pela postura ou pelo modo de se vestir. Transformam-se em heróis das crônicas de jornais, e depois alcançaram o teatro, o romance e o cinema. Devem muito à imprensa que, muitas vezes, colocaramnos em suas primeiras páginas. ${ }^{10}$

\footnotetext{
9 Termo utilizado e trabalhado por Diego Galeano. Para saber mais, ver: Criminosos viajantes. Circulações transnacionais entre Rio de Janeiro e Buenos Aires (1890-1930). Rio de Janeiro: Arquivo Nacional, 2016.

${ }^{10}$ Michelle Perrot se refere ao Petit Journal, Le Petit Parisiense, Le Journal e Le Matin. Jornais com tiragem de mais de um milhão de exemplares. Assumindo um caráter de massa, estavam no centro da moda. PERROT, Michelle. op. cit., p. 344 e 345.
} 
O exemplo é dado na crônica, já citada nesta monografia, do dia 21 de dezembro de 1910, publicada pelo O Paiz, que destaca o espaço dado aos apaches e seus feitos pela imprensa parisiense:

Os diários parisienses enchem, com frequência, suas páginas e colunas reservadas no registro de tais fatos, tendo sempre o cuidado de estampar a efigne desses cavalheiros tão notáveis com a enumeração dos seus gloriosos feitos, dos seus "vulgos" mais famosos, das heroicidades que, mais uma vez, praticado, dos seus amores picarescos, dos seus hábitos, dos seus costumes, dos seus gostos e predileções, dos seus vícios requintados ou vulgares, e até, com títulos e legendas sugestivas, nas ilustrações de que se serviram para a prática do crime. E, assim, o apache vai vencendo a resistência que de toda parte lhe oferecem, vai matando, vai roubando, vai tripudiando e vai zombando das medidas policiais e judiciárias que lhe opõem e vai fazendo estremecer de susto e de pavor a gente honesta, a gente que não quer cair na sua garra adunca, que não quer ficar sob seu pulso formidável, sob sua lâmina acerada, sob seu revólver homicida. ${ }^{11}$

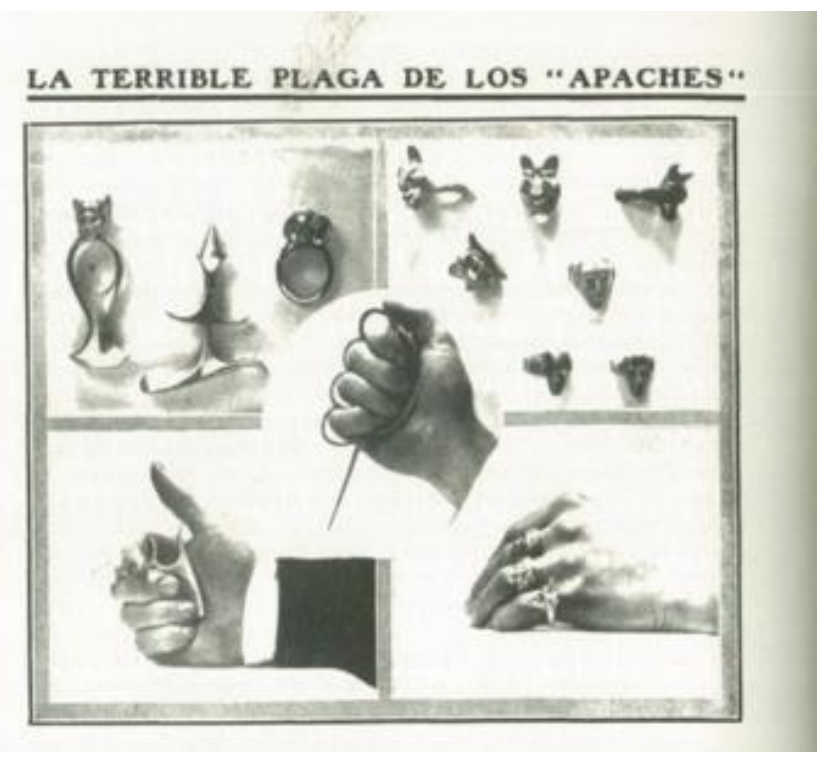

Imagem 4: As temidas armas apaches, objetos de bisturi convertidos em armas brancas (Mundo Gráfico, Rio de Janeiro, 23 de março de 1913, reproduzido em HOZ: 2016, 508)

Aos poucos, os apaches foram se transformando mais do que em velhos bárbaros indígenas, eram os bárbaros mais temíveis, os verdadeiros inimigos internos, fruto de uma civilização em marcha, passando a interrogar o século em que viviam e algumas de suas contradições. É nesse contexto que jornais e publicistas difundem a

11 "Os três tiras". O Paiz, Rio de Janeiro, 21 de dezembro de 1910. 
imagem de uma civilização ameaçada por essa horda de "novos bárbaros". Dessa forma, a associação entre os índios da América e os bárbaros parisienses aos poucos vai distanciando a imagem do índio da do bom selvagem, e assim perdendo sua força frente a figura mais inquietante do proletário como selvagem.

Michelle Perrot destaca que, face a uma crise geral das disciplinas tradicionais, em especial a retração das formas autônomas de organização industrial, em função do rigor estabelecido pelas fábricas, a juventude ocupa um lugar de destaque. Opondo-se aos velhos costumes da família patriarcal, quando aos dezoito anos cessa o controle da carteira de trabalho controlada pelo pai, o jovem operário abandona o lar e ganha as estradas, iniciando um turn over, cai em decadência sob todas as formas, rompendo com a hereditariedade dos ofícios e destruindo a transmissão dos saberes de pai para filho.

A figura do jovem operário passa a ser vista como a de alguém que tem que ser domado. Não suportando, esse jovem escapa do rigor do castigo e da hostilidade. Em consequência, o jovem operário é negado como indivíduo, a juventude popular é negada como grupo. Sem estrutura, ela não é reconhecida na sociedade. Os clãs das escolas primárias, bandos de ruas ou de bairros passam a ser as formas espontâneas de agrupamentos de uma juventude cuja sociedade não lhe reconhece existência coletiva.

Em vista desse quadro, aos poucos, as estatísticas alarmavam as autoridades com os índices de delinquência aumentando entre as faixas etárias de 16 a 21 anos. $^{12}$ Esses índices permitiam que uma parcela da opinião pública denunciasse principalmente a frouxidão dos magistrados, acendendo o debate na imprensa em relação ao rigor da lei ao punir os crimes realizados pelos apaches e a aplicação dos castigos físicos.

Para o Sr. Lépine, chefe de polícia de Paris, “os apaches existem, porque os magistrados não cumprem a lei de forma adequada". No dia 24 de setembro de 1910 , $O$ Paiz publicava uma crônica em que Lépine denunciava a indulgência dos tribunais.

\footnotetext{
${ }^{12}$ Entre 1830 e 1835, havia menos de 10 mil delinquentes entre 16 e 21 anos; em 1893, o número aumentou para 37 mil; de 1893 a 1914, o índice de delinquência já era superior a 10\% da mesma faixa etária. Para saber mais detalhes sobre estatística, ver PERROT, Michelle. op. cit., p. 352 e 353.
} 
Para ele, "se a lei fosse aplicada sem hesitação, a lei por completo, os apaches não iriam continuar a sorrir de suas proezas. O mal seria consideravelmente atenuado quando os juízes se mostrarem mais severos". 13

A mesma crônica informava que Lépine havia mostrado ao redator do "Le Martin" vários dossiês que a prefeitura possuía sobre centenas de malfeitores que andavam livremente pelas ruas de Paris - segundo ele, são apaches conhecidos. Isso porque, presos em flagrante delito, iam para o tribunal e o juiz, evocando circunstâncias atenuantes, condenava-os a penas mínimas. Voltavam da prisão para o Bulevar e ali recomeçavam as passadas proezas. E, Lépine acrescentava, “dessa forma a polícia fica impotente diante da má vontade dos tribunais, da indulgência do júri e da proteção que gozam tantos malandrins". ${ }^{14}$

Um exemplo foi publicado pelo jornal O Paiz, em 13 de fevereiro de 1912, sobre o caso do apache Liabeuf, que apunhalou três policiais e matou a tiro um outro agente de segurança. $\mathrm{O}$ crime foi um ato de vingança porque Liabeuf julgava-se perseguido e acreditava ser uma vítima do ódio policial. Argumentava que a polícia podia acusá-lo de todos os crimes, menos de viver às custas de prostitutas. Contudo, a polícia surpreendeu-o um dia recebendo dinheiro das mãos de um pierreuse do bulevar Sebastopol, e o tribunal o condenou a três meses de prisão, não podendo voltar à Paris nos cinco anos seguintes.

No entanto, assim que o malandrin saiu da penitenciária, dirigiu-se logo à Paris, onde trabalhou durante três meses como sapateiro com o objetivo de conseguir recursos para comprar um revólver e um punhal para pôr em prática seu plano de vingança. Estava com a ideia fixa de dar cabo dos agentes de polícia que o prenderam, e que para ele eram a causa da situação de desgraça a qual se encontrava. Esperou o momento oportuno para sua ambiciosa vingança. Porém, Liabeuf não encontrou os agentes que procurava e foi detido por outros e ele violentamente matou um deles a sangue frio. ${ }^{15}$

\footnotetext{
13 “A opinião de Lépine sobre a indulgência dos tribunais". O Paiz, Rio de Janeiro, 24 de setembro de 1910.

14 “A opinião de Lépine sobre a indulgência dos tribunais". O Paiz, Rio de Janeiro, 24 de setembro de 1910.

15 "O crime em Paris" O Paiz, Rio de Janeiro, 13 de fevereiro de 1910.
} 
No dia 25 de agosto de 1910, O Paiz publicou um novo episódio relacionado a Liabeuf. Dessa vez, tratava-se de um indivíduo que feriu mortalmente um agente de polícia à paisana e deixou em perigo de vida mais dois agentes da autoridade policial. Esse ato seria para vingar Liabeuf. ${ }^{16}$

O crime do Bulevar Sebastopol provocou em Paris um movimento geral de indignação. Todos reclamavam medidas enérgicas contra os criminosos, que se diziam vingadores de Liabeuf, com o simples intuito de fazer mal pelo sádico prazer de verdadeiros criminosos.

\subsection{0 chicote como forma de punição aos apaches}

Os dois episódios mencionados acima reacenderam um debate que a tempos circulava entre as autoridades e publicistas franceses. O jornal carioca O Paiz, no dia 16 de setembro de 1910, publicou uma crônica cujo título era "Dar cabo do apache? Eis uma das grandes preocupações do legislador moderno".

Essa crônica apresentava o posicionamento de vários publicistas que defendiam o uso do chicote como forma de punição aos apaches. O jornal Correio Paulistano, no dia 24 de outubro de 1910, publicou uma extensa crônica referente aos castigos físicos adotados pelas prisões inglesas. Como informava a crônica, as prisões inglesas serviam como exemplo ao adotarem o chicote, ou melhor, o tão comentado na época, "gato de nove caudas".

O "gato de nove caudas" surgiu na Inglaterra em 1689 e até metade do século XIX foi utilizado em castigos corporais. Foi em 1860 que o Parlamento autorizou os juízes, pelo Garrotters Act, a acrescentar a pena do chicote à da prisão, no caso de agressões contra as pessoas. O "gato de nove caudas" não foi, apesar disso, empregado antes de 1880.

Havia, em Londres, neste momento, uma quantidade grande de vagabundos noturnos que atacavam e esbordoavam os transeuntes. Para acabar com este

\footnotetext{
16 "Os infratores de Liabeuf. Os apaches contra a polícia". O Paiz, Rio de Janeiro, 25 de agosto de 1910.
} 
problema, aplicou-se com rigor o Garrotters Act e os apaches ingleses não mais entraram nas prisões. O método consistia em despertar antes o medo do que a dor propriamente dita. De acordo com texto publicado no Correio Paulistano, em 24 de outubro de 1910:

O medo age, além disso, em tal caso, mais ainda que o próprio mal, quase todos os prisioneiros gritam desesperadamente antes mesmo que o gato tenha acariciado as suas carnes. Foi assim que o chicote "expurgou Londres, em menos de dezoito meses, dos apaches que infestavam a cidade há trinta anos". ${ }^{17}$
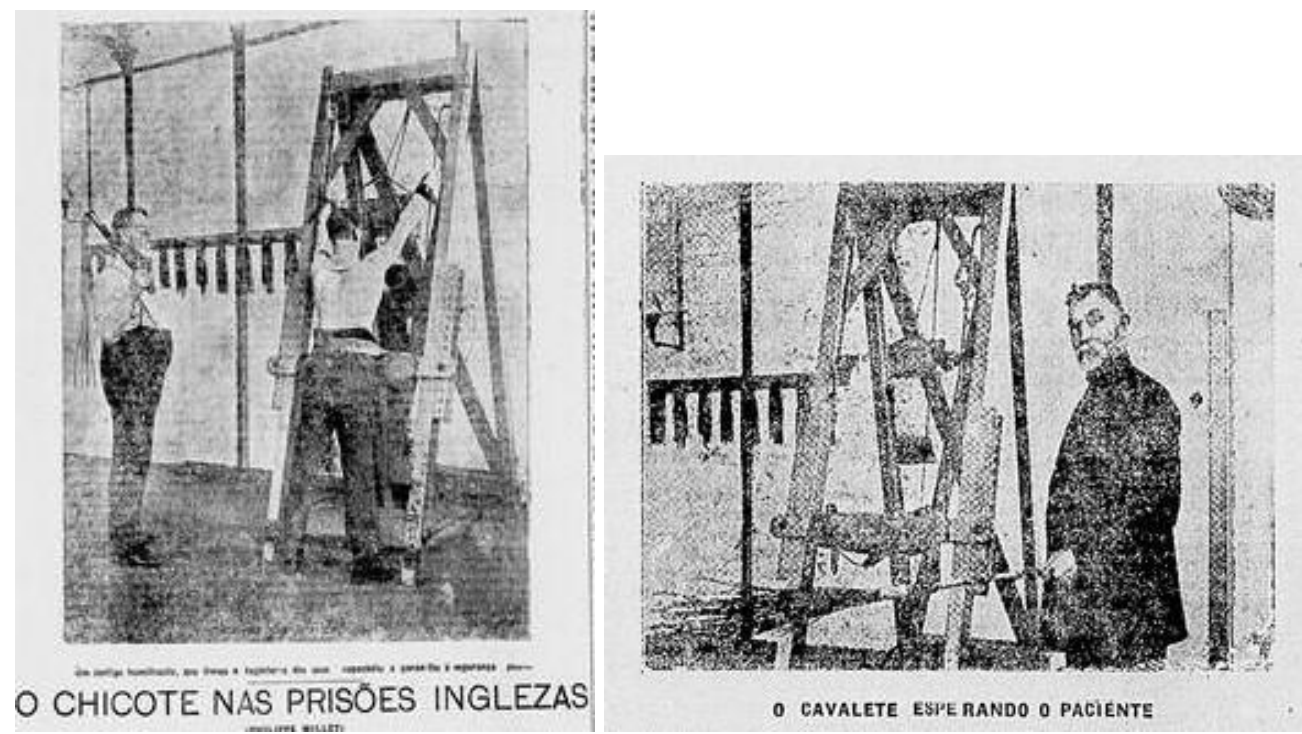

Imagens 5 e 6: Fotos tiradas pelo correspondente do Illustration de Paris na prisão Wormswood Serubbs, Inglaterra. Correio Paulistano, São Paulo, 24 de outubro, 1910.

Na França, as opiniões entre magistrados se dividiam - um grupo defendia que não era possível corrigir crimes praticando crimes e o único meio racional e congruente de punir os transgressores seria mesmo a prisão. A grande questão para eles era se os castigos corporais, como exemplo da Inglaterra, realmente conseguiriam atingir o objetivo pretendido que era, através do medo, promover um saneamento de bandidos dessa natureza. Para este grupo:

\footnotetext{
${ }^{17}$ Essa crônica descreve detalhadamente o funcionamento do cavalete criado especialmente para a aplicação do castigo corporal com o "gato de nove caudas". Ver: "Os chicotes nas prisões inglesas" Correio Paulistano, 24 de outubro de 1910.
} 
O apache era uma consequência lógica e fatal do estado natural das coisas, da balbúrdia daquele momento, da confusão mental de que a humanidade se encontrava. O crime é em grande parte, o resultado inevitável dos desvarios, das imprevidências e dos erros governamentais. Mata-se o apache e deixa-se que os fabricantes de armas lhes preparem e lhes vendam os hediondos instrumentos, que lhes servem para a prática dos seus hediondos assassinos. Mata-se o apache, que viverá abandonado a vida inteira, a quem foram criadas as múltiplas dificuldades, e que, em regra, é um produto mórbido de heranças e influências mesológicas. Tudo isso não faz mais do que arriçar e açular mais fortemente esses rancores, esses ódios, essas inclinações. ${ }^{18}$

Por outro lado, a inadequação dos modos de repressão, o conforto das prisões e a falência de um sistema penal que nem se quer amedrontava os delinquentes uniam, na época, outra parcela de juristas de tribunais criminais em uma posição oposta. Jornais como o Le Petit Journal e Le Matin, policiais, políticos, magistrados e médicos lideravam a campanha contra a brandura das penas. Para esse grupo, o efeito do castigo físico para jovens, particularmente vaidosos, se refletia em uma situação de humilhação.

Despido, ou quase, o apache expõe sua anatomia de fraco e degenerado; ele se mostra tal como ele é, um ser inferior que só a nossa excessiva humanidade tolera no seio das grandes cidades. $\mathrm{Na}$ condição de flagelado em que se encontra, torna-se desonrado perante aos seus, que não o aceitam como chefe, o que destrói e mina o bando. As moças que contribuíam para a sua existência passam a rejeitar um homem açoitado, e aos poucos o apache vai perdendo a sua auréola de crime que constitui a sua força. ${ }^{19}$

No Brasil, esse debate era tratado pelo diretor do Gabinete de Identificação e editor da revista Boletim Policial, Elysio de Carvalho. Autor de obras como História natural dos malfeitores: notas e crônicas e A Fisionomia da criminalidade carioca. Em uma crônica no jornal O Imparcial, publicada em 19 de outubro de 1913, cujo título era "A apologia do chicote como pena judiciária”, Elysio de Carvalho defendia que as leis da época não protegiam suficientemente a sociedade contra os malfeitores. Isso porque, segundo ele:

\footnotetext{
18 “Os três tiras". O Paiz, Rio de Janeiro, 21 de dezembro de 1910.

${ }^{19}$ Paris, Librairie du Temple, 1910, p. 116 (B.N. 8. ${ }^{\circ}$ R23565) apud Perrot, Michelle. op. cit., p. 357.
} 
A mentalidade e a sensibilidade dos delinquentes não comportavam geralmente a suavidade do sistema penal vigente. Ele defendia o castigo corporal como o meio mais eficaz para impedir a recrudescência da criminalidade violenta: "o terror que inspira o chicote é mais que suficiente para refrear os maus instintos. ${ }^{20}$

Elysio de Carvalho citava também o exemplo da Inglaterra. Para ele, a receita deveria ser a mesma - o receio da dor física era mais do que necessário para manter os malfeitores em ordem. A medida era tida como eficaz por um motivo psicológico singular: o medo.

Fala-se do ataque à dignidade humana, como se os jovens delinquentes tivessem a noção da sua dignidade! O sentimento da sua dignidade de homens não existe, podemos quase afirmar à priori. O que é para nós a condição de honra e dignidade, não tem muitas vezes nenhum significado para o criminoso. $O$ instinto soube determinar neles os meios mais apropriados ao seu caráter para discipliná-los, quando se organizam em bandos: o medo. ${ }^{21}$

Elysio de Carvalho defendia que o castigo físico não seria apenas doloroso, mas também humilhante para o criminoso e oferecia, neste ponto de vista, uma ação moral efetiva. Ele asseverava que deploravam a ineficácia das leis repressivas vigentes, mas, questionava, o erro do sistema não viria de uma má análise da alma do criminoso? Isso porque, segundo ele, as penas eram ineficazes porque em muitos casos, não eram adequadas aos indivíduos as quais eram aplicadas. E finalizava:

O que marca um recuo na marcha da civilização não é a adoção da pena do açoite, é, justamente, a impotência do Estado em defender a ordem estabelecida e instituir a disciplina. À continuar assim, nessa atitude de exagerada piedade, acabaremos por fornecer aos senhores malfeitores chicote para nos bater. ${ }^{22}$

Na França, o grupo de magistrados que defendiam uma política de prevenção, uma política da infância e de uma ampliação de uma rede mais ramificada de forças policiais acabou vencendo. O resultado, segundo Michelle Perrot, foi a instauração de

\footnotetext{
20 "A apologia do chicote como pena judiciária”, O Imparcial, Rio de Janeiro, 19 de outubro, 1913.

21 “A apologia do chicote como pena judiciária", O Imparcial, Rio de Janeiro, 19 de outubro, 1913.

22 "A apologia do chicote como pena judiciária", O Imparcial, Rio de Janeiro, 19 de outubro, 1913.
} 
um verdadeiro Código da Infância, em 1912, com a criação de tribunais para menores e assistência de psicólogo judicial.

No entanto, essa parcela da juventude escapou a esses cuidados. Para Perrot, a única coisa prevista para esses jovens parisienses era o serviço militar, como forma de domar os rebeldes impertinentes e prepará-los para as linhas de frente quando a guerra chegasse. ${ }^{23}$ Esse seria o fim do "momento apache" na França? Possivelmente, sim, mas os que conseguiram escapar da perseguição policial traçaram as suas rotas de fuga e iniciaram uma verdadeira diáspora rumo a outros países da Europa, como a Espanha. Na América do Sul, seria a vez de Buenos Aires, Montevidéu e Rio de Janeiro viverem o seu "momento apache".

\subsection{Apaches na Espanha}

No dia 5 de agosto de 1916, o diário carioca Fon Fon publicou uma crônica informando a emigração de apaches franceses para Madrid. Atribuía esse movimento migratório aos efeitos da guerra, principalmente por causa do desaparecimento dos estrangeiros e da ida da maioria dos homens para guerra que, com isso rareavam as ocasiões de roubo. Somando a isso, as tabernas e as locandas esvaziavam-se e as ameaças da polícia com o estado de sítio permanente fizeram com que esses criminosos buscassem outros espaços para a prática do crime. Como destaca a crônica:

Foi uma emigração como qualquer outra e movida pelas mesmas causas de todas - o interesse, a necessidade de viver. Os apaches parisienses escolheram a capital mais próxima de Paris, os bandidos foram "fazer" Espanha - país dos bandidos, que tem bandoleiros em Andaluzia, contrabandistas na Catalunha e salteadores em Sierra Morena. O certo é que os bandidos aventureiros da Espanha eram verdadeiros aprendizes perto dos grandes mestres e profissionais do crime, formados pela escola de Paris, os Berton, os Gautriaud, os Lucien Vienne. ${ }^{24}$

O historiador espanhol Raúl Gimero de Lo Hoz, ao tratar do fenômeno apache em Madrid, ressalta que o apache genuíno, na França, já estava em processo de

\footnotetext{
${ }^{23}$ PERROT, Michelle. op. cit., p.359.

24 "Emigração de apaches", Fon Fon, Rio de Janeiro, 5 de agosto de 1916.
} 
extinção com a chegada da Primeira Guerra. Muitos deles haviam sido recrutados como "carne de canhão" e não haviam voltado, e os que haviam sobrevivido tiveram que se reinventar.

A França, naquele momento, exportava moda, ódios e vícios e o apache havia se convertido no criminoso por excelência; seu estilo de vida despertou rapidamente a admiração da imprensa sensacionalista espanhola. Demorou pouco para os periódicos trazerem a público a presença de apaches na Espanha (não se sabe ao certo, mas a data de 1904 parece marcar o aparecimento das primeiras referências de apaches em solo espanhol). Em alguns casos, os periodistas reclamavam da moda do apachismo que dominavam as notícias: "Há homens honrados e só se fala de apaches! Há ações de virtude, de abnegação sublimes, e não se fala mais do que de apaches!"25

-A PACH E S E N MAD R I D

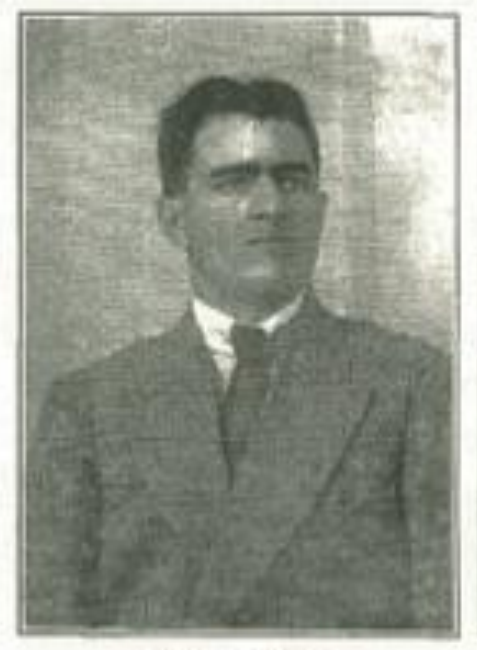

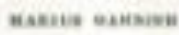

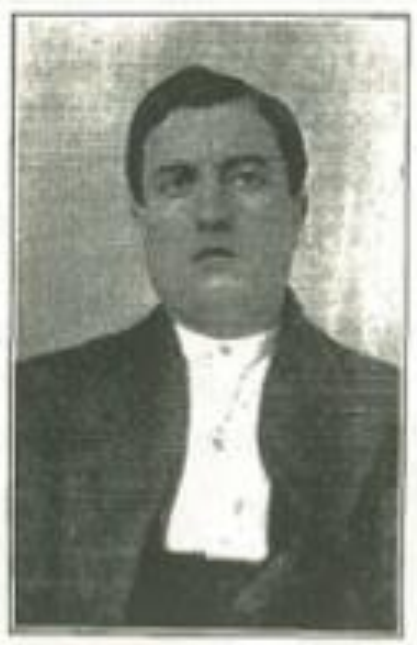

Eibes atenass

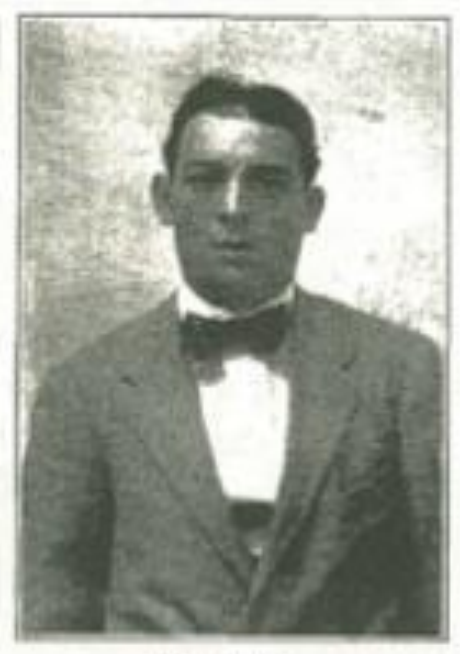

ksw kave

Imagem 7: Fotos dos apaches Marius Garnier, Isidoro Gautriaud e Luís Berton (publicadas no diário Nuevo Mundo, 16 de junho de 1916, reproduzido em HOZ: 2016, 493)

Segundo Hoz, o periodista Mariano de Cavia foi um dos primeiros a confirmar a presença de apaches na Espanha e reforçava que a pressão policial em

\footnotetext{
25 HOZ, Raúl Gimero de lo. Apaches. In: Hampa, Anarquistas, Bandoleiros y Apaches. Los bajos fondos en España (1900-1923). Madrid: La Felguera Editores, 2016, p.479.
} 
solo francês era o que impulsionava a chegada de apaches em cidades como Barcelona, Madrid, Bilbao e Valência.

Em Barcelona, constatava-se uma maior presença de apaches devido a criação do bairro chinês e o fervor que despertou os cafés cantantes, as tabernas e locais que eram antros noturnos. ${ }^{26}$ Barcelona era uma ampla zona portuária em que a imagem apache se confundia com uma grande quantidade de tipos de toda classe de nacionalidades que por ali passavam. Muitos apaches não estavam fichados, e no caso de estarem, os sistemas de identificação eram precários e deficientes. Outros, simplesmente trocavam de imagem e ocultavam suas tatuagens para driblar a perseguição policial. Conforme noticiava a imprensa espanhola, tudo era parte de uma estratégia para preparar os golpes e permitir que eles se infiltrassem na Espanha.

Segundo Raúl Gimero, a chegada do apache em solo espanhol parece ter sido paulatina. Não foi só o olhar felino que aterrorizou a opinião pública, mas a exibição tão pouco usual, pelo menos em Madrid, das tatuagens. Estas, no começo do século, para os madrilenos, eram algo completamente inabitual, símbolo de indivíduos considerados selvagens. Nesse sentido, a presença de apaches na Espanha se converteu, desde então, em um elemento frequentemente mal visto.

A Espanha passou a ser vista como um local transformado pela nefasta influência francesa, foco de uma epidemia de apachismo. Contudo, no começo dos anos vinte, as notícias referentes aos apaches começaram a desaparecer. Muitos acabaram sendo presos ou mortos, e outros, simplesmente, se dedicaram a outra atividade.

No Brasil, o assimilacionismo do que era parisiense estava expresso na crítica da crônica do periódico Fon Fon, de 26 de outubro de 1912, ao tratar do apache como uma nota genuinamente parisiense:

Então, porque havemos de rejeitar essa nota civilizadora, que a cidade luz tão liberalmente nos cede? Deixem vir os apaches, que com eles virão as gigolletes, que é a musa vagabunda do crime parisiense. O carioca de hoje, civilizado, prefere naturalmente assistir a todas as peripécias de um crime hediondo, cometido segundo as regras da criminalidade parisiense do apache, a ver as violências desengonçadas e

\footnotetext{
${ }^{26}$ Idem, p.484.
} 
rales de um crime executado pelas nossas antigas praxes criminais da Gamboa e da Saúde. $^{27}$

Frente a emigração de uma leva de criminosos parisienses, entre os anos de 1912 e 1913, as autoridades policiais de Buenos Aires, Montevidéu e Rio de Janeiro moveram uma intensa campanha para impedir o desembarque desses criminosos na América do Sul. Os apaches não mobilizaram somente a polícia dos países mencionados, mas também inspirou o imaginário das representações sociais por onde passaram. É o que será tratado a seguir.

27 “Apaches”, Fon Fon, Rio de Janeiro, 26 de outubro de 1912. 


\section{Capítulo 2 - Apaches vindos de Buenos Aires}

\subsection{A repressão policial}

No dia 20 de maio de 1913, o jornal carioca Correio da Manhã publicava uma extensa crônica cujo título dizia: "Apaches e ladrões, em numerosas turmas, passam pelo Rio a bordo dos grandes transatlânticos". ${ }^{28}$ Tal notícia informava em seu conteúdo o movimento de caftens, ladrões e apaches que, vindos de Buenos Aires, devido ao cerco policial movido pela polícia portenha, tentavam desembarcar dos grandes transatlânticos nos portos do Rio de Janeiro.

Esse movimento havia se iniciado na França, conforme tratado anteriormente, porque lá a perseguição policial havia se tornado intensa, principalmente a partir da primeira década do século XX. Dessa forma, os apaches iniciaram um movimento de dispersão alcançando principalmente, aqui na América do Sul, Buenos Aires, Rio de Janeiro e Montevidéu.

Não foram poucas as notícias dadas pelos principais jornais do Rio referente ao tema. No dia 11 de maio de 1910, o Correio da Manhã já noticiava na sessão "Pelo Thelégrafo" que, em Buenos Aires, "a polícia desenvolveu grande atividade contra a chegada de indivíduos suspeitos, que na sua maioria são conhecidos como 'apaches' parisienses". ${ }^{29}$

Já no dia 27 de setembro de 1911, o mesmo jornal noticiava a prisão, a bordo de um transatlântico inglês, "provavelmente vindo da Europa", de quatro apaches que tentavam desembarcar na capital argentina. ${ }^{30}$ E no dia 15 de setembro de 1912, o Correio da Manhã, em uma crônica intitulada "Apaches", "dá a conhecer a presença de uma importante quadrilha de apaches que aportou aqui no Rio de Janeiro, perseguida pela polícia de Buenos Aires". ${ }^{31}$

\footnotetext{
28 "Os canfinfleros", Correio da Manhã, Rio de Janeiro, 20 de maio de 1913.

29 "Pelo telégrafo - Notícias de Buenos Aires", Correio da Manhã, Rio de Janeiro, 11 de maio de 1910.

30 "Apaches na Argentina”, Correio da Manhã, Rio de Janeiro, 27 de setembro de 1911.

31 "Notícias do interior", Correio da Manhã, Rio de Janeiro, 15 de setembro de 1912.
} 


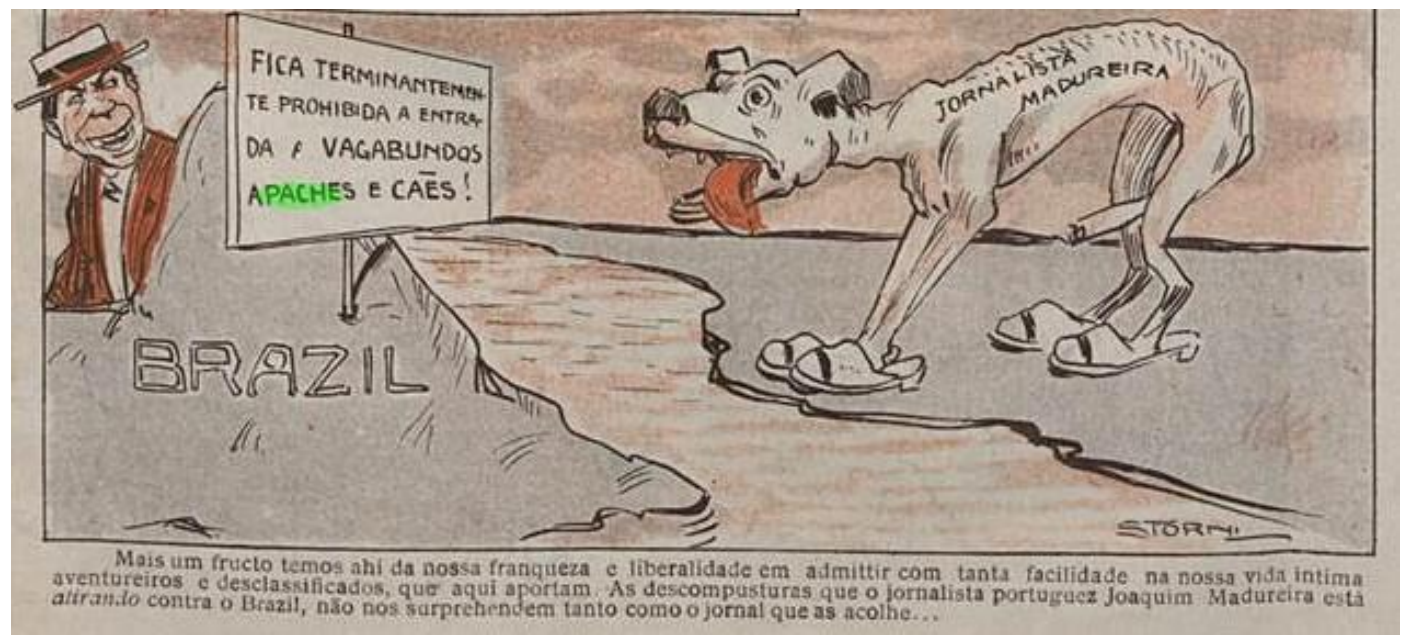

Imagem 8: Charge publicada no jornal $O$ Malho, Rio de Janeiro, em 9 de maio de 1914.

Este intenso movimento de criminosos no mundo atlântico não se deu somente devido à perseguição policial das respectivas localidades, mas também pelo fato de existirem inovações tecnológicas da modernidade que operavam em um duplo sentido, ou seja, ao mesmo tempo em que eram armas usadas contra os ladrões, operavam a seu favor quando eram utilizadas pelos mesmos para burlar a ação da polícia local.

A mobilidade territorial era facilitada pela revolução nos transportes, que segundo Diego Galeano, em Criminosos Viajantes, apresenta a figura do "ladrão viajante" e o surgimento do crime internacional. ${ }^{32}$ Ladrões viajantes eram aqueles que não tinham residência fixa, mudavam sempre de identidade e viajavam sempre após os roubos, dificultando a ação da polícia.

Foi a partir dessa onda imigratória de criminosos "viajantes" que a polícia de Buenos Aires começou a agir. A cidade portenha estava repleta deles e os cronistas daquela cidade, como Soiza Reilly, narravam em 1912 o percurso que eles faziam pelos bares para tramarem seus roubos. ${ }^{33}$ Mas, no final do mesmo ano, como mostra Galeano, a revista Sherlock Holmes noticiava, "que os apaches estavam sendo

\footnotetext{
${ }^{32}$ GALEANO, Diego. Criminosos Viajantes. Circulações transacionais entre Rio de Janeiro e Buenos Aires (1890-1930). Rio de Janeiro: Arquivo Nacional, 2016, p. 150.

${ }^{33}$ SOIZA REILLY, Juan José de. Buenos Aires tenebroso: los apaches apud GALEANO, Diego. Criminosos Viajantes. Circulações transacionais entre Rio de Janeiro e Buenos Aires (1890-1930). Rio de Janeiro: Arquivo Nacional, 2016, p. 151.
} 
expulsos para seus países de origem devido a lei de expulsão de estrangeiros da Argentina". ${ }^{34}$ Uma crônica sobre a expulsão dos apaches de solo argentino, publicada pela mesma revista, ilustrava com seis fotografias os criminosos expulsos no porto, carregando seus pertences em direção aos transatlânticos.

Mas o trabalho da polícia argentina não se encerrava aí. A preocupação com o desembarque desses criminosos em portos vizinhos como os de Montevidéu e Rio de Janeiro fazia com que as autoridades policiais desses países estivessem em contato permanente. Isso porque o retorno desses criminosos ao país de que foram expulsos era quase certo.

A notícia, já citada, do Correio da Manhã, do dia 20 de maio de 1913, informava que "de quando em quando, por um telegrama, é a nossa polícia informada pela sua colega de Buenos Aires, do embarque de vários criminosos". 35 Foi a partir da primeira década do século XX que as polícias, principalmente da Argentina e do Brasil, empreenderam uma vigilância mais acirrada ao fluxo de suspeitos que transitavam pelas rotas atlânticas sul-americanas. Um dos artifícios usados pelas polícias locais dos respectivos países para garantir a expulsão desses indivíduos foram as leis de expulsão de estrangeiros sancionadas na Argentina (1902) e no Brasil (1907).

Somando a isso, as polícias de Buenos Aires, Rio de Janeiro e Montevidéu tinham estabelecido um canal de intercâmbio de informações que permitiam rastrear antecedentes criminais como prova nos processos de expulsão. A troca de telegramas entre as autoridades policiais da Argentina e do Rio de Janeiro contribuíram para uma vigilância mais intensa nos portos dessas cidades, impedindo o desembarque de estrangeiros que tinham maus antecedentes e que haviam sido expulsos da Europa ou de outros países da América do Sul.

A notícia do dia 20 de maio de 1913 informa também sobre o desembarque de um conhecido ladrão, Armando Origone, que daqui já havia sido expulso duas vezes. Diante de tais informações, a polícia do Rio, a partir de suas investigações, chegou à conclusão de que aqui operava uma numerosa quadrilha que envolvia caftens,

\footnotetext{
${ }^{34}$ GALEANO, Diego, op. cit., p. 151.

35 "Os canfinfleros", Correio da Manhã, Rio de Janeiro, 20 de maio de 1913.
} 
apaches e cafinfleros. E o que viria a ser "cafinfleros"? Um velho oficial conhecedor do meio descreve ao repórter do Correio da Manhã o seu significado:

- "Cafinfleros"?

- Sim, Senhor, são também indivíduos que exploram mulheres de modos diversos, colocando-as em pontos onde nunca aparecem. O dinheiro vem sempre pelo correio.

- E há no Rio?

- Si os há? Mas, a grande escala. Mostro-lhe esta relação: estão aqui quase todos.

- Examinamos os retratos.

- São nomes já conhecidos através dos telegramas argentinos.

Dessa forma, foi a partir de investigações que incluíam a colaboração das autoridades argentinas que a Polícia Marítima do Rio de Janeiro constatou o desembarque de Armando Origone e de outros indivíduos de nomes Pablo Hollander, José Rouchet, Maurício Zico, Pablo Luz, Michel Luz, Carlo Bouchet e Antonio Lemousin.

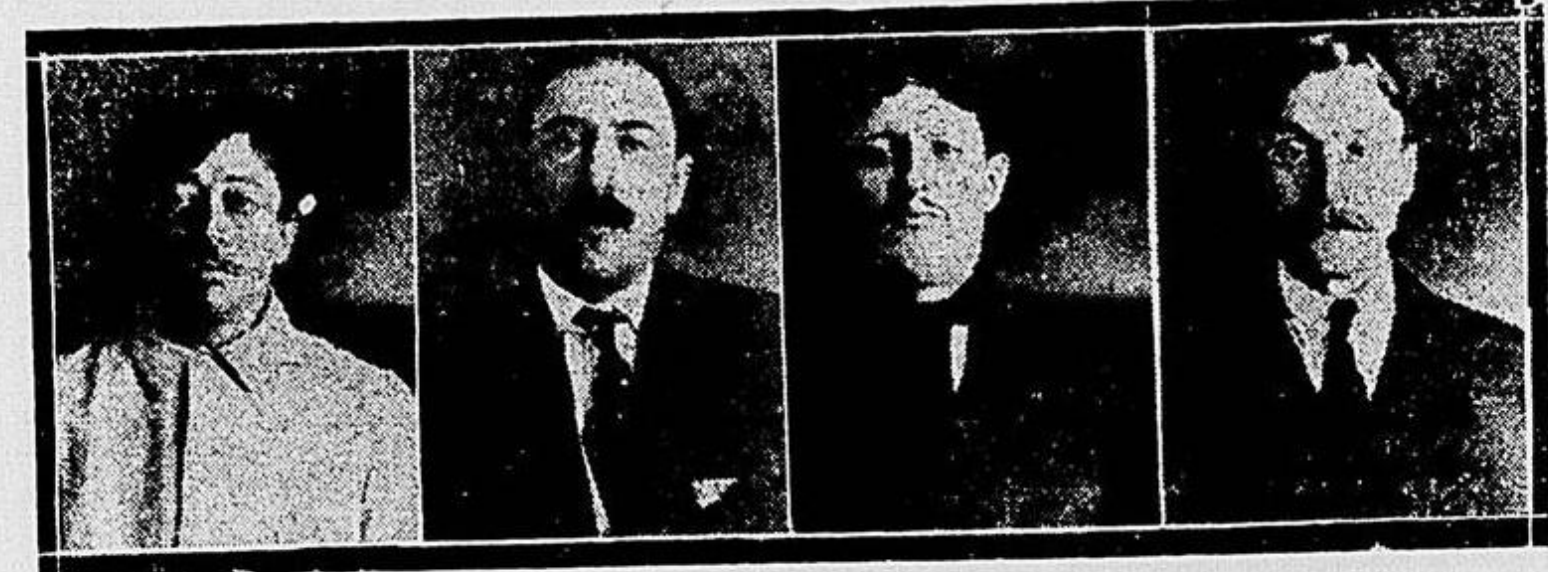

\section{PABLO HOLLANDE, JOSE' ROCHET, MAURICIO ZICO E PABLO LUE}

Imagem 9: Indivíduos expulsos pela polícia argentina e que tentaram desembarcar no porto do Rio de Janeiro. Correio da Manhã, Rio de Janeiro, 20 de maio de 1913. 


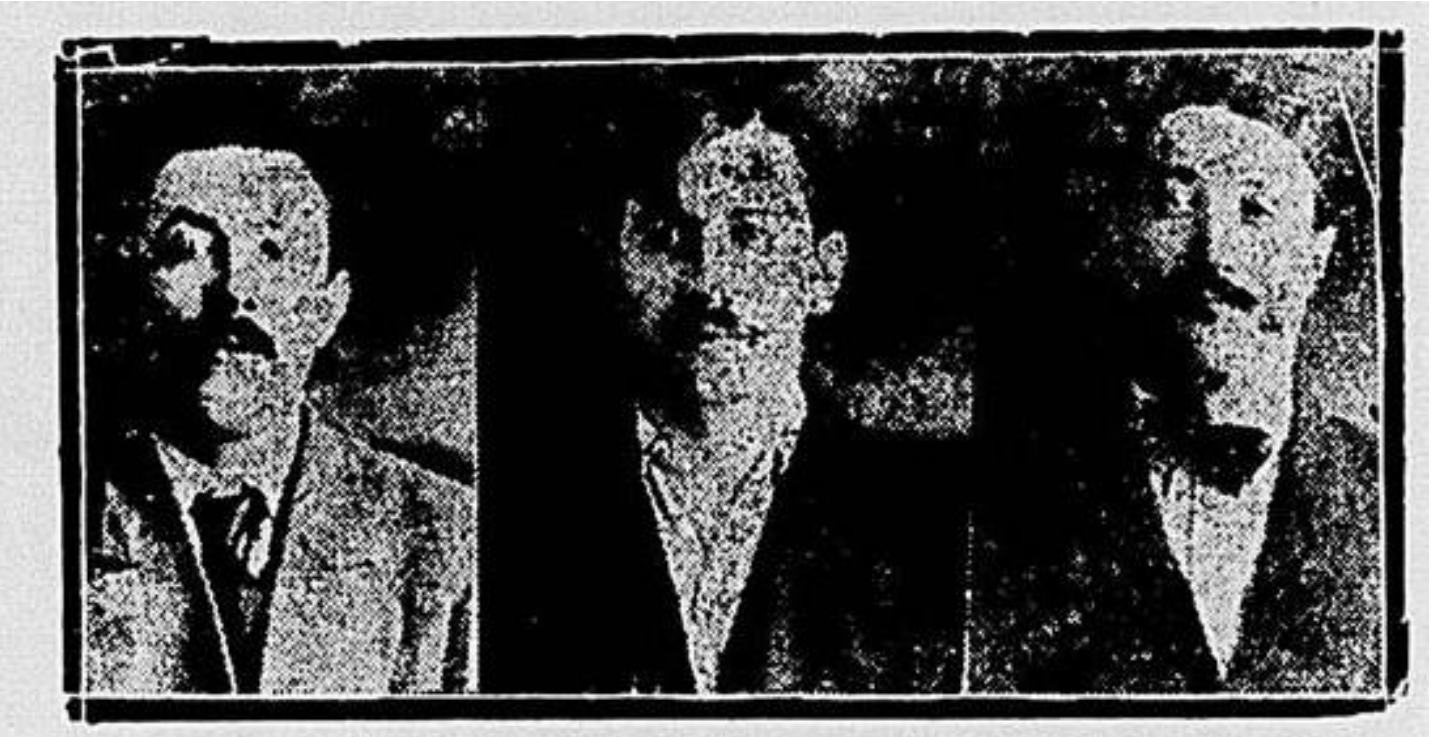

\section{MTCHEL LUZ, CARLO BOUCH ET E ANTOINE LEMOUSIN}

Imagem 10: Indivíduos expulsos pela polícia argentina e que tentaram desembarcar no porto do Rio de Janeiro. Correio da Manhã, Rio de Janeiro, 20 de maio de 1913.

Os cafinfleros, na gíria portenha, eram os exploradores de mulheres e, nesse mundo delitivo, o crime associava roubo, morte (se fosse preciso matar) e lenocínio. Geralmente, os apaches vindos da França vinham acompanhados de "suas mulheres". $\mathrm{Na}$ verdade, os apaches nunca estavam só, viviam em grupos que se ajudavam e se protegiam. Michelle Perrot os descreve como "bandos" e afirma que eram muito organizados: "Quase parecem ser apenas associações de amigos (...). Em torno de um núcleo firme, aglutina-se uma camada de flutuantes que aderem ou largam o núcleo conforme as circunstâncias". ${ }^{36}$ E eram geralmente em bandos que esses indivíduos atravessavam o Atlântico e desembarcavam na Argentina.

Quando tentavam desembarcar no porto do Rio de Janeiro, eram perseguidos; assim, tentavam retornar a Buenos Aires ou incluir em seus roteiros outras cidades como São Paulo e Montevidéu.

A notícia do dia 16 de setembro de 1912 no Correio da Manhã informa sobre o comunicado da polícia argentina para o $2^{\circ}$ delegado auxiliar do Rio de Janeiro, Dr. Ferreira de Almeida, acerca da expulsão de 80 apaches e ladrões com destino aos

\footnotetext{
${ }^{36}$ Perrot, Michelle. op. cit., p. 346.
} 
portos de Santos, Rio de Janeiro e Europa, mas a mesma notícia alertava que "mesmo com todo o rigor que a polícia marítima exerce nem sempre ela pode impedir que este ou aquele indivíduo iluda a vigilância a bordo e escape". 37

\subsection{0 jornalismo investigativo}

Nesse contexto de perseguição policial, vale destacar o papel do jornalismo investigativo. No início do século XX, João do Rio, considerado o precursor do jornalismo investigativo no Brasil, marcou e redefiniu o jornalismo, dando uma guinada que mudaria os parâmetros da prática jornalística no país. Em sua "etnografia do cotidiano", fez da observação uma marca do seu trabalho. ${ }^{38}$

Dessa forma, a ida ao campo passava a oferecer uma leitura da realidade e inspirou o trabalho de vários outros jornalistas. O trabalho de alguns deles que se ocuparam da cobertura da repressão policial de apaches no solo carioca não se limitou somente ao simples fato de informar a prisão e a expulsão de apaches. Eles foram a “campo" e lançaram o seu "olhar etnográfico", tema trabalhado por Julia O’Donnell em De olho na Rua. A cidade de João do Rio. ${ }^{39}$

Ao investigar, os jornalistas chegaram, muitas vezes, a alguns criminosos procurados pela polícia. Acrescentando informações e enriquecendo as matérias, transformaram algumas notícias referentes aos apaches em verdadeiros folhetins, despertando o interesse do leitor.

Se antes as notícias eram curtas, com poucas informações e sem ilustrações, com o tempo, passaram a compor um conteúdo que incluía fotos e diálogos. O tema apache ganhou o interesse do público e, em 1915, ganharia também destaque nas representações carnavalescas, assunto que será tratado mais adiante neste trabalho.

\footnotetext{
37 "A polícia argentina captura 80 apaches", Correio da Manhã, Rio de Janeiro, 16 de setembro de 1912.

${ }^{38}$ João do Rio (1881-1921) fez das ruas do Rio o palco de suas perambulações. Foi o seu hábito de "flanar" que acabou retratando o modo de ser e o estilo de vida dos agentes sociais de sua época. O resultado foi a publicação de uma série de textos na imprensa carioca entre 1904 e 1907 e depois reunidos na obra $A$ alma encantadora das ruas. Para saber mais, ver: RIO, João do. A alma encantadora das ruas: crônicas. São Paulo: Companhia das Letras, 2008.

${ }^{39}$ Para saber mais, ver O'DONNELL, Julia. De olho na rua. A cidade de João do Rio. Rio de Janeiro: Zahar, 2008, pp. 90-91.
} 
Mas voltemos às investigações jornalísticas. No dia 17 de outubro de 1912, o Correio da Manhã publicava uma crônica cujo título era "O Correio da Manhã fala a vários ‘apaches' expulsos pela polícia de Buenos Aires”.

O conteúdo da matéria tratava de telegramas enviados pelo general Dellepiane, chefe de polícia de Buenos Aires, ao $2^{\circ}$ delegado auxiliar do Rio de Janeiro, Dr. Ferreira de Almeida, informando que a bordo do transatlântico Pampa haviam embarcado seis apaches expulsos de Buenos Aires de nomes Alberto Lopes, Villar Neil, Ferdinando Luis Darouk, Miguel Luiz e José Solar ${ }^{40}$. Os telegramas mencionados pela imprensa, de fato, existiram, como o da imagem apresentada abaixo.

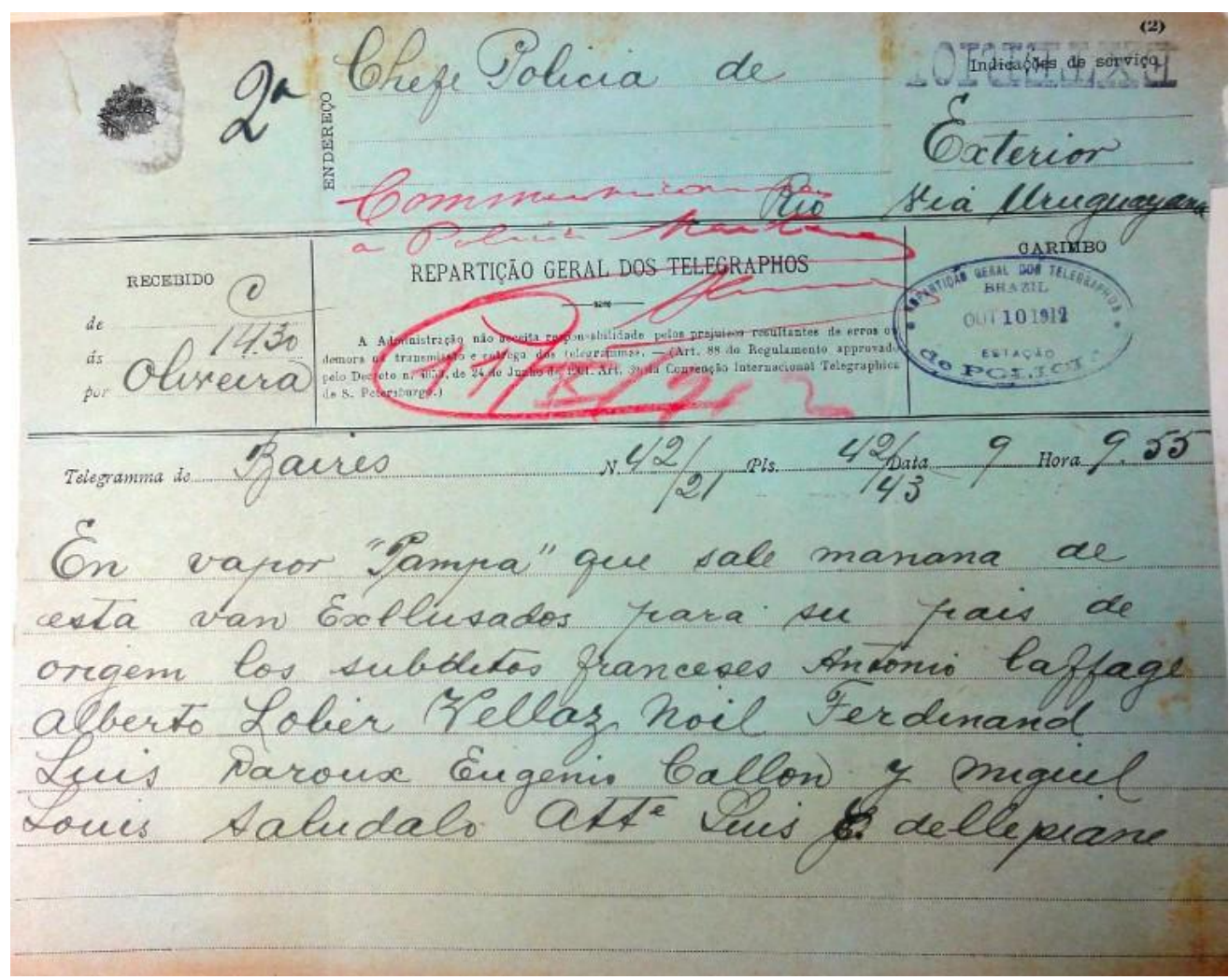

Imagem 11: Telegrama da polícia de Buenos Aires enviado à polícia carioca.

Arquivo Nacional, Fundo da Secretaria de Polícia do Rio de Janeiro, GIFI 6C 392, out. 1912.

40 "O Correio da Manhã fala a vários apaches expulsos pela polícia de Buenos Aires". Correio da Manhã, Rio de Janeiro, 17 de outubro de 1912. 
Em seu trabalho de "campo", o repórter do Correio da Manhã não perdeu tempo e foi verificar as informações recebidas pela polícia. A bordo do Pampa, interrogou Alberto Lopes:

- Percebo, jornalista, repórter...

- Sim, senhor.

- Os senhores em toda a parte. E olhe, nesse caso, se a polícia nos persegue, é por culpa vossa. Em tudo acham pretexto para noticiar escândalos.

- Mas o que fizeram e porque foram expulsos?

- Porque a polícia suspeitou de nós. O Sr. Dellpiane teve denúncia de que fazíamos parte de uma grande quadrilha que a polícia parisiense perseguiu e que se refugiou em Buenos Aires, e daí a perseguição que nos moveu.

- Não seriam expulsos, claro, se não houvesse um motivo imperioso.

- Motivo? Se a polícia não dá tempo que a gente procure se defender... Encartou-se no cérebro de um agente que tínhamos em mente assaltar uma joalheria na calle de Mayo e daí a nossa prisão.

- Estiveram muito tempo presos?

- Alguns dias.

O nosso fotógrafo aproximou-se.

- Vai nos fotografar?

- Se permite...

- Nunca!

Essa não foi a única matéria em que repórteres fizeram investigação e interrogatório a criminosos se antecipando à polícia. Quando os criminosos escapavam do cerco policial, eles perseguiam pistas e chegavam até os mesmos muito antes da polícia. Tentavam uma aproximação e aos poucos conseguiam arrancar dos meliantes as informações que queriam. Bastava saber que algum deles havia escapado, que a busca começava.

Esse novo jornalismo que já nas últimas décadas do século XIX mostrava a sua face, era representado pelas grandes folhas, de caráter mais comercial, constituindo a grande imprensa do Brasil. Leonardo Afonso Pereira, ao tratar da atuação dos literatos do final do século XIX na imprensa do Brasil, pontua esse marco com o surgimento do jornal A Gazeta de Notícias, em 1874. Segundo ele, umas das propostas do seu fundador, Ferreira de Araújo, era de que o jornal não estivesse ao alcance de apenas uma parcela específica da sociedade. Para isso, F. Araújo inaugurou o sistema de vendas avulsas pela cidade e promoveu transformações na 
estrutura dos textos, tornando a leitura mais fácil, o que deu um caráter mais popular ao jornal.

Posteriormente, outros jornais seguiram o mesmo caminho da Gazeta de Notícias, como O Paiz, O Diário de Notícias e o Jornal do Brasil, o que despertou o interesse do público e mudou o hábito de leitura dos jornais. A partir daí, "tornava-se comum, no período, a leitura em voz alta desses jornais, que passaram assim a informar também a grande massa de iletrados que se espalhava pela cidade". 41

Em meio às transformações ocorridas nos principais jornais do país da época, esse movimento do jornalismo investigativo muito contribuiu para o trabalho de busca das autoridades policiais. A crônica publicada pelo Correio da Manhã, no dia 27 de setembro de 1912, cujo título era "Como a nossa reportagem descobre dois apaches vindos de Buenos Aires", tratava do desembarque no porto do Rio de Janeiro de dois apaches que viajavam clandestinamente no transatlântico Vandick, vindo de Buenos Aires: Lebon e Hessed, o primeiro de nacionalidade austríaca e o segundo, "filho legítimo de Paris", como declararam ao repórter do Correio da Manhã, no comércio Café Avenida, à Rua das Marrecas, aonde foi feita a reportagem:

- Na camaradagem que procuramos entreter com os dois indivíduos, de casquette, gola levantada, lenço ao pescoço e cigarro atrás da orelha, que la conversavam, num francês de argot, molhando a palavra com exageradas doses de whisky, foi-nos muito fácil obter as seguintes notas, que oferecemos à polícia:

Lebon e Hessell são dois indivíduos sem profissão, que, perseguidos pela polícia de Buenos Aires, conseguiram embarcar, clandestinamente, para o Rio de Janeiro, no transatlântico inglês Vandick, chegando de Buenos Aires no dia 24 do corrente. Fizeram toda a viagem escondidos e passaram três dias sem comer e sem dormir. Chegando ao Rio, deixaram os seus esconderijos e desembarcaram, iludindo a vigilância da polícia marítima. ${ }^{42}$

Essa crônica acrescenta à notícia uma narrativa de informações obtidas a partir do trabalho investigativo do repórter e de um tipo de abordagem que permitiu uma aproximação entre ele e os criminosos Lebon e Hessel.

\footnotetext{
${ }^{41}$ PEREIRA, Leonardo Affonso de Miranda. O carnaval das letras. Literatura e folia no Rio de Janeiro do século XIX. São Paulo: UNICAMP, 2004, p. 40.

42 "Deportamento de apaches", Correio da Manhã, Rio de Janeiro, 27 de setembro de 1912.
} 
Vale destacar que a imprensa francesa nesta época ocupava uma posição central e as narrativas folhetinescas francesas atravessavam o Atlântico e chegavam ao Brasil. Nesse momento, o romance judiciário, como de Émile Gaborie, era tido como referência. ${ }^{43}$

O que chamava a atenção nessa recente modalidade narrativa da época era colocar o investigador como figura central e, consequentemente, a descoberta do crime. $\mathrm{O}$ inovador estava na maneira de revelar o crime e o criminoso. Somando a isso, segundo Ana Porto, a partir da década de 1870, narrativas de crime começavam a ganhar espaço nos periódicos sob a forma de notícias, folhetins e volumes, indicando a possibilidade da existência de uma cultura midiática e massificada no Brasil neste momento.

Exibindo um discurso muito próximo daquele apresentado pela polícia, os periódicos reinventavam no espaço do jornal uma outra forma de apresentação, mais ágil e adaptada para criar um efeito impressionante no leitor e gerando, também, sensação", 44

Dominique Kalifa pontua que entre os anos de 1830-1840, na França, a função dos jornais passa por uma transformação inquietante e radical. Ela não mais é um dispositivo argumentativo, mas sim, representativo, passando a retratar a sociedade em seus mais variados elementos, utilizando como meio a narrativa:

Há um interesse popular pela transgressão, pela ruptura social, que é de grande importância e que reaparece quando os jornais de grande tiragem recuperam esse imaginário. Daí resulta que essas histórias de crime, que são tradicionais e que são veiculadas por um dispositivo editorial cada vez mais maciço, são histórias que contam aos leitores ordinários, qualquer coisa de suas próprias vidas, de suas próprias histórias. Dessa forma, o leitor passa a ser o objeto do próprio consumo, ou seja, o que a cultura de massa está consumindo como acontecimento é espetáculo de nós mesmos. As histórias criminais são histórias ordinárias, que podem acontecer com

\footnotetext{
${ }^{43}$ Ana Porto aborda em artigo apresentado no XXVII Simpósio Nacional de História, Natal, junho de 2013 a trajetória do autor, a produção de todos os seus romances de sucesso - dentre eles, L' Affaire Lerouge (1866), Le Crime d'Orcival (1866-67), Le Dossie $n^{\circ} 113$ (1867), Monsier Lecoq (1868) - e a repercussão de sua obra no Brasil.

${ }_{44}^{44}$ Artigo apresentado pela autora no XXVII Simpósio Nacional de História, Natal, RN, 22 a 26 de julho de 2013, p.8.
} 
gente ordinária, portanto, com os consumidores da cultura de massa, que são, ao mesmo tempo, os leitores e os objetos do consumo cultural. ${ }^{45}$

A partir daí, podemos entender que ao transmitir a notícia, a mídia jornalística aciona um sistema de representações ao qual o público leitor se identifica e reconhece como parte da sua própria realidade.

\subsection{0 crime de lenocínio}

O lenocínio foi uma prática muito presente no universo apache que merece uma atenção especial. Tratado pelas autoridades como "escravatura branca", "tráfíco de brancas" ou mesmo lenocínio ${ }^{46}$, foi muito combatido tanto pelas autoridades internacionais de Buenos Aires como as do Rio de Janeiro. Algumas notícias referentes a apaches dão a saber a presença de mulheres que acompanhavam esses criminosos e eram exploradas pelos mesmos.

No dia 30 de setembro de 1911, o jornal A pacotilha informava sobre a chegada de uma quadrilha de apaches, chefiada por Jean Boucher, composta de cinco mulheres e sete homens. ${ }^{47}$

O Correio da Manhã, na crônica do dia 12 de setembro de 1913, cujo título era "Michel Molinez e sua amante Fols desvendam à polícia o mistério da vida em comum, na Vila Cruzeiro" informava do cerco que a polícia estrangeira estava fazendo aos "mercadores das brancas", isso segundo a matéria, graças à intervenção da Sociedade Protetora das Mulheres. Estes indivíduos embarcavam com destino a América e saltavam, de preferência, nos portos do Rio de Janeiro e Buenos Aires. Mudando de nomes, de filiação e aparentando vida de comerciantes, eles se

\footnotetext{
${ }^{45}$ Entrevista concedida a Marcos Luiz Bretas e Diego Galeano, e publicada na Revista Topoi, v. 13, n. 25, jul./dez. 2012, p. 187.

${ }^{46}$ H.D. Barruel de Lagenest, em Lenocínio e Prostituição no Brasil, faz uma distinção entre prostituição e lenocínio. Segundo ele, "a palavra prostituição exprime o fato de uma mulher entregar seu corpo para atividades sexuais, por dinheiro e sem amor, e isso de modo habitual; já a palavra lenocínio, conforme reza o artigo do Código Penal, quer dizer tirar proveito da prostituição alheia, participando diretamente de seus lucros, e fazendo-se sustentar em todo ou em parte por quem a exerce". Para saber mais, ver: LAGENEST, H. D. Barruel de. Lenocínio e prostituição no Brasil. Rio de Janeiro: Agir, 1960.

47 "Notícias do exterior", A Pacotilha, Rio de Janeiro, 30 de setembro de 1911.
} 
instalavam, exploravam suas vítimas até que uma denúncia anônima ou um fato de rua os colocavam em evidência. Mais adiante a crônica acrescentava que:

A polícia está às voltas, no momento presente, com um fato bem interessante e que chegou ao seu conhecimento por intermédio de uma carta. $\mathrm{O}$ denunciante, que ocupa um quarto da Vila Cruzeiro, à Rua do Riachuelo $n^{\circ} 303$, conta cenas interessantes de um casal que se instalara no quarto $n^{\circ} 6$ e cuja mulher, de 4 da tarde à meia noite, não aparecia em casa. Dizia-se que era uma escrava. O seu dono, amigo de um outro indivíduo que ocupava outro apartamento, com duas outras raparigas de vida duvidosa, era um tipo sobre o qual a polícia deveria exercer severa vigilância. ${ }^{48}$

\section{A mesma crônica segue com mais informações:}

No dia 23 de julho deste mesmo ano desembarcaram aqui, a bordo do Cobur, Miguel Molinez e sua amante Marie Folo, Joaquim A. Redondo Vege, e a prima desta, Pura Cuesta Martinez.

Miguel e Marie, que traziam em sua companhia uma criança de 7 anos, de nome Vicente, hospedaram-se num hotel qualquer. Não conheciam o Rio e tomaram esta providência até que estudassem bem o centro onde iam conviver. $\mathrm{O}$ outro, velho conhecedor do meio, instalou as duas raparigas que trouxe na rua General Câmara, e entrou a tirar proveito da situação de ambas.

Marie Folo conheceu Molinez na Algeria, quando ele fazia o serviço militar. Amou-o e deixou o marido para acompanhá-lo à América, trazendo o seu filho Vicente, que o pai repudiou.

Aqui, sustentava o amante. De 4 à meia noite, diariamente, ela ia para a Rua Joaquim Silva. Carmen e Pura Cuesta eram exploradas por Joaquim Redondo Vega. Tinham as suas rótulas na Rua da Conceição, 6 e 8, onde permaneciam de 10 à meia noite, hora em que entregavam a feria ao miserável. ${ }^{49}$

48 "Plano de apaches", Correio da Manhã, Rio de Janeiro, 12 de setembro de 1913.

49 "Plano de apaches", Correio da Manhã, Rio de Janeiro, 12 de setembro de 1913. 


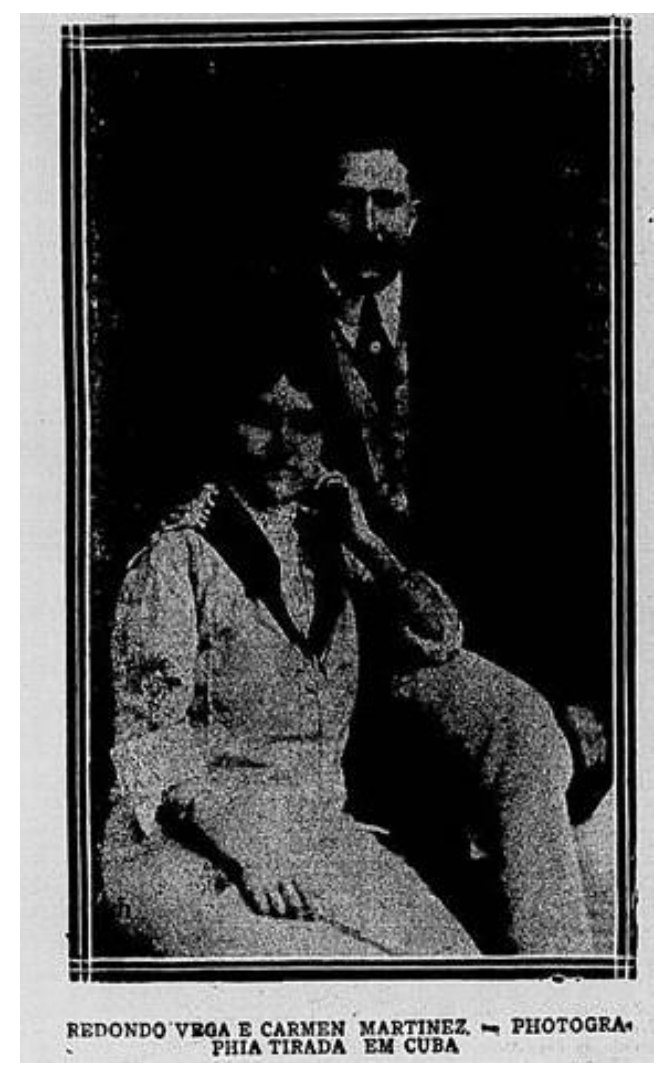

Imagem 12: Redondo Vega e Carmem Martinez.

Correio da Manhã, Rio de Janeiro, 13 de setembro de 1913

Este foi um dentre tantos outros casos relatados pela imprensa de apaches que migravam para a América com suas companheiras para explorá-las em pontos estratégicos da cidade. Voltando à crônica do Correio da Manhã, do dia 20 de maio de 1913, a campanha movida pelo $2^{\circ}$ delegado auxiliar do Rio de Janeiro, Dr. Ferreira de Almeida, contra o comércio da escravatura branca estava repercutindo na Argentina. Em seu conteúdo consta um ofício publicado pelo general Dellepiane e recebido pelo ministro da justiça de Buenos Aires solicitando medidas severas contra os que praticavam o tráfico de mulheres:

A.S.E., El señor Ministro del Interior - Tuve el honor de dirigir-me a V.E. em nota fecha 22 de abril año próximo passado, demonstrando la necesidad de ditar medidas tendientes à reprimir la imoralidad del comercio y exploración de mujeres. Es un asunto que a seguido preocupando la atención de esta jefatura, porque considera que no debe permanecer como espectadora ante la ación de esos sujetos que vive de un negocio vergonzoso y que debiera estar penado. (...) Esa gente dispone de dinero en 
abundancia para poner el ejercicio su influencia maleana y buscar por todos os medios la impunidad para su indigno negócio"(...). ${ }^{50}$

De acordo com Michelle Perrot, as mulheres ocupavam um ponto central em relação ao aspecto violento dos apaches. Elas eram frequentemente procuradas por questões de dinheiro, mas também desempenhavam o papel de amantes, pertencentes a um homem. "Como espiãs, hábeis mensageiras e ocasionalmente podendo manejar a navalha, seduzem as vítimas e auxiliam nos roubos."

O casal apache foi muito representado na caricatura francesa, como é o caso de "Saída do cárcere", de Herman Parl, representando a mulher que vai esperar o apache na saída da prisão, para "recompensá-lo com mimos e dinheiros". 52
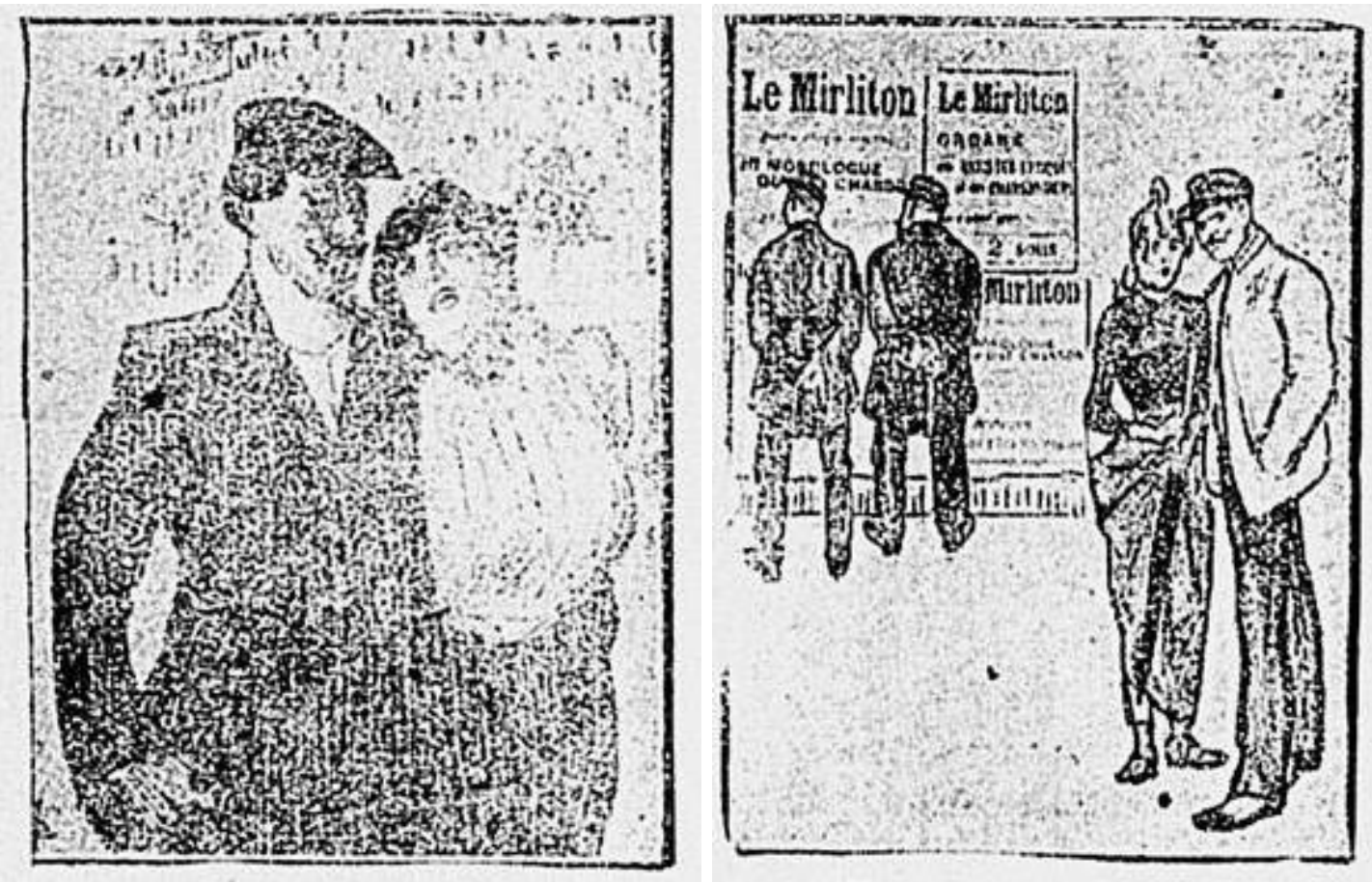

Imagem 13: Saída do cárcere de Herman Parl Gazeta de Notícias, Rio de Janeiro, 16 de fevereiro de 1916.

\footnotetext{
50 "Os canfinfleros" Correio da Manhã, Rio de Janeiro, 20 de maio de 1913.

${ }^{51}$ PERROT, Michelle, op. cit., p. 348 e 349.

52 “Saída do Cárcere”, Gazeta de Notícias, Rio de Janeiro, 16 de fevereiro de 1916.
} 
Apesar de toda campanha movida pelas polícias de Buenos Aires e do Rio de Janeiro na repressão e expulsão dos apaches, os mesmos deixaram a sua marca em sua passagem pela América do Sul, inspirando na Argentina uma série de peças de tango, na qual se destacou "El apache argentino" de Manuel Aroztegui. ${ }^{53}$

Nos teatros do Rio de Janeiro, era comum algum quadro de apaches, como no espetáculo "Porte-Bonheur", encenado pelos bailarinos "Sta-Elia". ${ }^{4}$ O Teatro Apollo também incluía um quadro de apaches em sua programação. ${ }^{55}$ Já o teatro República divulgava que "o ator Carlos Leal, entre outros, terá a seu cargo o papel da gigolette, a dama do dueto dos apaches, papel em que o estimado artista fará diabruras do arco da velha". 56

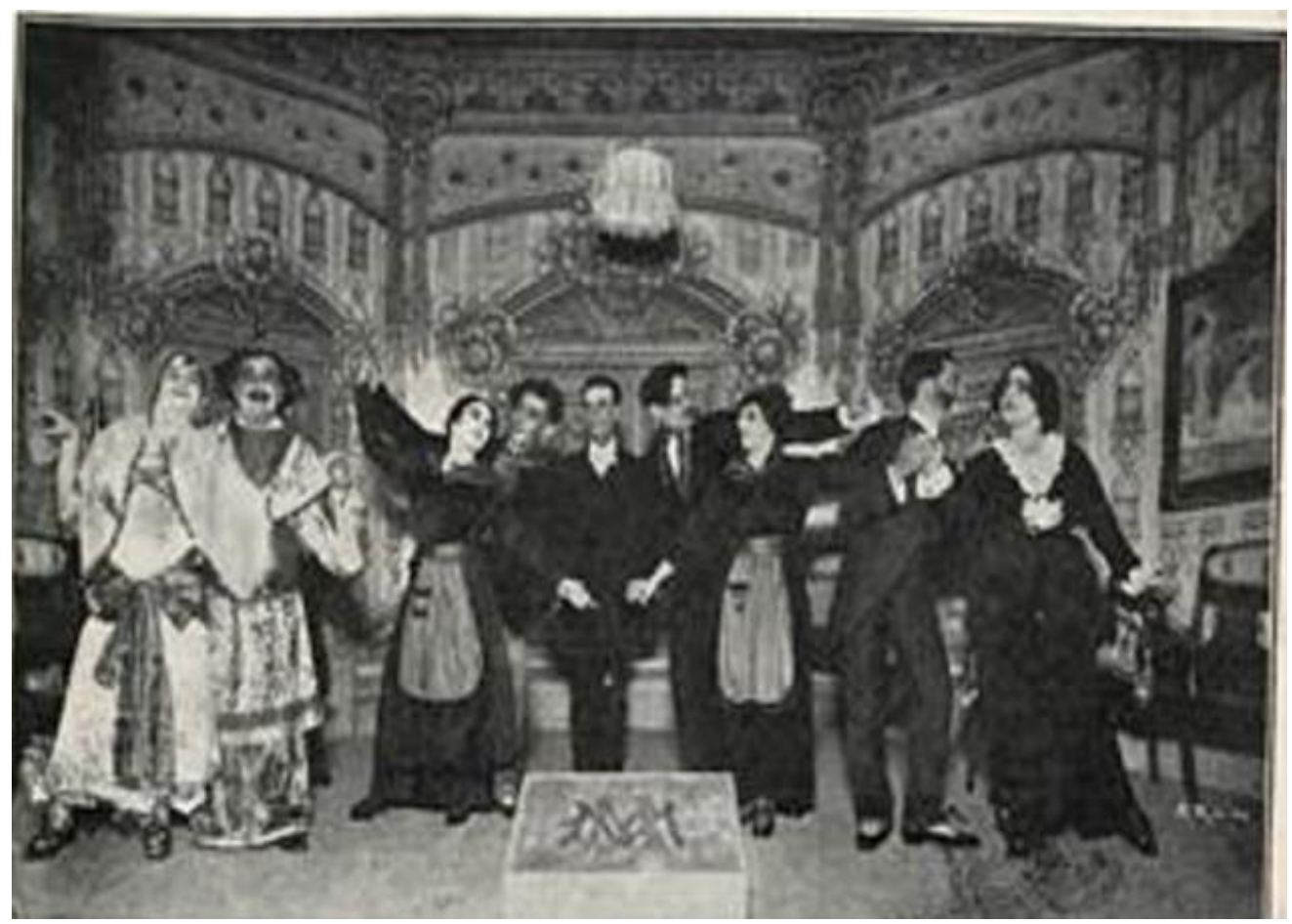

Imagem 14: Cena final da burleta em 1 ato Apaches em casa, de E. Wanderley, teatro Trianon. Fon Fon, Rio de Janeiro, 20 de março de 1915.

\footnotetext{
${ }^{53}$ Como destaca Diego Galeano, a letra do tango de Manoel Aroztegui aproximava a figura do apache parisiense ao personagem tangueira do compadrito, que representava elementos envolvidos em brigas com facas nos subúrbios portenhos, apagando, desta forma, a história dos criminosos viajantes de origem francesa. Ver: GALEANO, Diego, op. cit., p.152.

54 "Espetáculo Porte-Bonheur", Correio da Manhã, Rio de Janeiro, 7 de janeiro, 1915.

55 "Teatro Apollo", Correio da Manhã, Rio de Janeiro, 15 de janeiro, 1915.

56 "Teatro República", Correio da Manhã, Rio de Janeiro, 11 de fevereiro, 1915.
} 
A dança dos apaches com uma performance peculiar desperta o gosto e sensação no público. É o que o diário Fon Fon publica em uma nota:

Gosto - porque não dizer - da moderna estética luxuriosa dos apaches e gigolletes no macabro desequilíbrio da dança dos apaches. Acho naquele desajeito de gesticuladas, qualquer coisa de empolgante, que nos põe os nervos a tinir e os olhos a saltar de admiração. ${ }^{57}$

No dia 24 de outubro de 1913, o jornal Correio da Manhã publica uma crônica cujo título é "O último bando", referente a uma estatística de "caftens" e "apaches" que vindos de Buenos Aires passaram pelo porto do Rio de Janeiro a bordo dos grandes transatlânticos. Esta estatística apresenta cento e vinte nomes, dentre eles de homens e mulheres das mais diferentes nacionalidades. Segundo o repórter do Correio da Manhã, ao se aproximar, um pequeno grupo deixou-se fotografar, com uma condição: que seus nomes fossem dados por eles mesmos. Falsos? Segundo ele, "é bem possível, mas as caras são autênticas e a polícia pode muito bem guardá-las para seu uso futuro". 58

\footnotetext{
57 "Bilhetes à cora", Fon Fon, Rio de Janeiro, 10 de agosto de 1912.

58 "O último bando", Correio da Manhã, Rio de Janeiro, 24 de outubro de 1913.
} 


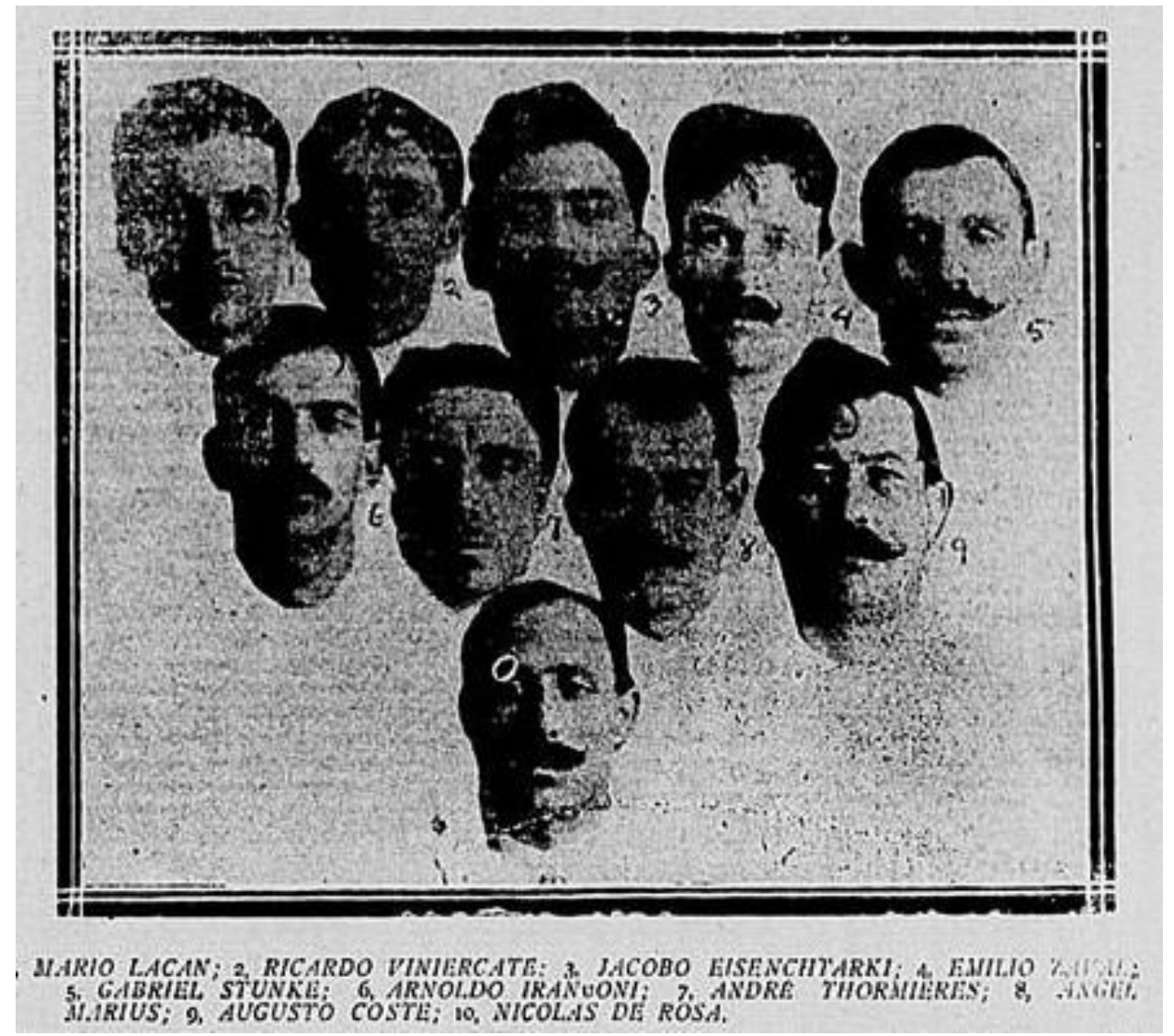

Imagem 15: Foto do "último bando" registrada pelo Correio da Manhã, Rio de Janeiro, 24 de outubro de 1913.

A passagem do "último bando" pode ter sido registrada pelo Correio da Manhã em outubro de 1913, mas as marcas do "momento apache" carioca permaneceram no imaginário da sociedade, inspirando as manifestações culturais da época.

Em 1915 as fantasias de apaches e gigolletes deram o tom da festa do Momo durante três dias de folia e seus feitos eram cantados nas letras dos blocos de apaches. $\mathrm{Na}$ verdade, o verdadeiro "fenômeno apache" foi a magia sedutora que esses profissionais do crime imprimiram no imaginário da sociedade e que a repressão policial não foi suficiente para eliminar ou exportar de volta a seu ponto de origem. 


\section{Capítulo 3 - Apaches e gigolletes no carnaval do Rio de Janeiro de 1915}

\subsection{Blocos e fantasias}

Ao trabalhar com o tema "apache" a partir da bibliografia e das fontes jornalísticas que tenho citado ao longo desse trabalho, pude perceber que precisamente na América do Sul (nesse caso estou tratando de Buenos Aires, Montevidéu e Rio de Janeiro) o "fenômeno apache", iniciado na França, foi amplamente incorporado, seja por vários criminosos de outras nacionalidades - como mostra a crônica "O último bando", do jornal carioca Correio da Manhã, tratados pela imprensa de "apaches" -, seja por manifestações culturais, como o carnaval carioca de 1915.

As fantasias de apaches e gigolletes, assim como blocos carnavalescos de várias localidades da cidade que assumiam o nome de "apaches", denunciam um movimento cultural que assumia as características do apachismo nascido na França.

Poderíamos considerar este um fenômeno local, onde um grupo heterogêneo da sociedade carioca se identificava com as representações de tais figuras, ou seria uma forma de se manifestar criticamente quanto a temas como a criminalidade e a questão de gênero tão em debate na época?

Maria Clementina Pereira Cunha, em sua obra Ecos da Folia, publicada em 2001, nos mostra que os préstitos carnavalescos no Rio de Janeiro, desde a década de 1870, já tratavam de temas recorrentes carregados de críticas como a questão da escravidão, da política imperial e a questão militar. Segundo a autora:

As alusões jocosas a tais temas não tinham o propósito de apenas fazer o público rir,
mas também de ensinar e fazer o mesmo público a pensar de acordo com os seus
próprios parâmetros. Muito cedo essa intenção foi assumida pelas sociedades
carnavalescas, transformando em baluartes de propaganda e popularização as causas
em destaque na sociedade. Foi em um tom eminentemente "panfletário" que as
sociedades em graus diferentes incorporaram em seus préstitos tais temas.

\footnotetext{
${ }^{59}$ CUNHA, Maria Clementina Pereira. Ecos da Folia: uma história social do carnaval carioca entre 1880 e 1920. São Paulo: Companhia das Letras, 2001, pp. 135-136.
} 
A questão do apachismo, tão divulgada pelos principais jornais do país, principalmente entre os anos de 1912 e 1913, aparece nas representações carnavalescas da época. Em 1915 tal fenômeno passa a inspirar as marchinhas de vários blocos de carnaval no Rio de Janeiro e a caracterizar as fantasias de homens e mulheres da sociedade carioca. Há uma clara conexão entre a conjuntura de 1912/1913 e o carnaval de 1915; a febre pelos apaches neste carnaval não se explica sem a conjuntura anterior.

Durante três dias de folia, o "fenômeno apaches parisienses" passou a habitar o imaginário da população carioca na festa do Momo de 1915. Segundo a cobertura dada pelos principais jornais da cidade, as fantasias de apaches e gigolletes ganharam destaque nos principais bailes carnavalescos, incluindo os bailes infantis. $\mathrm{O}$ fenômeno se manifestou também em vários blocos, conforme noticiado no Correio da Manhã de 14 de fevereiro do ano corrente: "a nota do dia de ontem, em nossa redação, foi dada pelo interessante e afinado grupo de apaches de São Cristóvão, composto das mais gentis senhoritas do aristocrático bairro e de rapazes das principais famílias $(\ldots) " \cdot 60$

Bem organizados, os blocos tinham sede, diretoria e versos próprios como os "Salteadores da Calábria":
Nós somos "apaches"
ao povo vamos roubar
mas com tanta presteza
p'ra polícia não nos pegar.
Nós somos apaches
somos destemidos
não brinquem conosco
porque senão saem despidos.

Segundo a matéria publicada no Correio da Manhã em $1^{\circ}$ de fevereiro de 1915, este grupo tinha sua sede à rua 25 de Maio, $n^{\circ}$ 68, e seus componentes vestiam trajes característicos de "apaches" e as senhoritas de "gigolletes". 61

\footnotetext{
60 “Apaches de São Cristovão”, Correio da Manhã, Rio de Janeiro, 14 de fevereiro de 1915.

61 "Salteadores da Calábria”, Correio da Manhã, Rio de Janeiro, $1^{\text {o }}$ de fevereiro, 1915.
} 


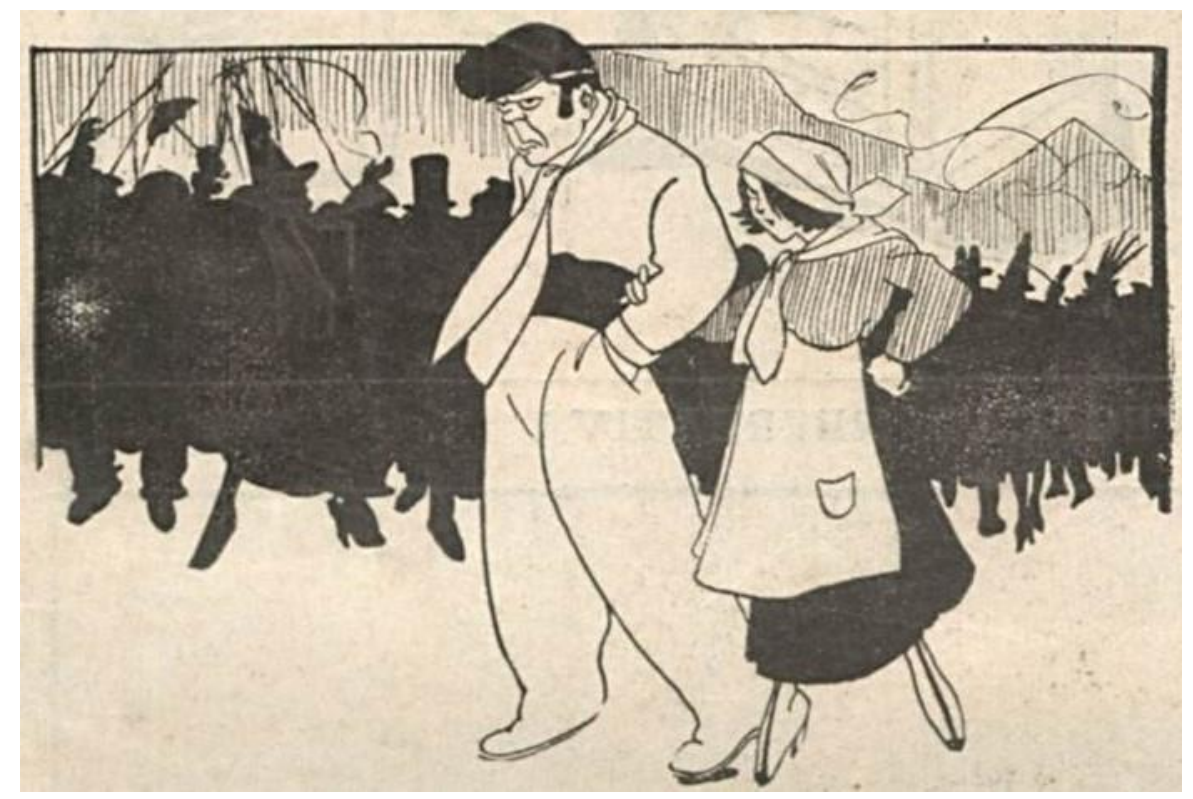

Imagem 16: Charge publicada no jornal $O$ Malho, Rio de Janeiro, 11 de março de 1916

Nos bailes infantis, as fantasias de apaches também ganharam destaque, como a matinée infantil no teatro Recreio. No dia 16 de fevereiro de 1915, o Correio da Manhã publicava que "Ondina e Álvaro, filhos do Sr. Manoel Pinto, do cinema Ideal, [eram] dois apaches de meter medo (...)"62 e em 16 de fevereiro daquele ano, O Paíz anunciava que João Rego Barros Filho trajava "interessante fantasia de 'apache", 63 No dia seguinte foi a vez do jornal A Época noticiar que "estiveram em nossa redação as meninas Jurema e Odette Moutinho, um gentil casal de apaches, primeiro prêmio da matinée infantil que 'A noite' ofereceu ontem à gurizada carioca”. 64

\footnotetext{
62 "O baile de ontem no Recreio foi uma festa encantadora", Correio da Manhã, Rio de Janeiro, 16 de fevereiro, 1915.

63 "Matinê infantil no Recreio", O Paíz, Rio de Janeiro, 16 de fevereiro, 1915.

64 “Adeus momo!, A Época, Rio de Janeiro, 17 de fevereiro, 1915.
} 


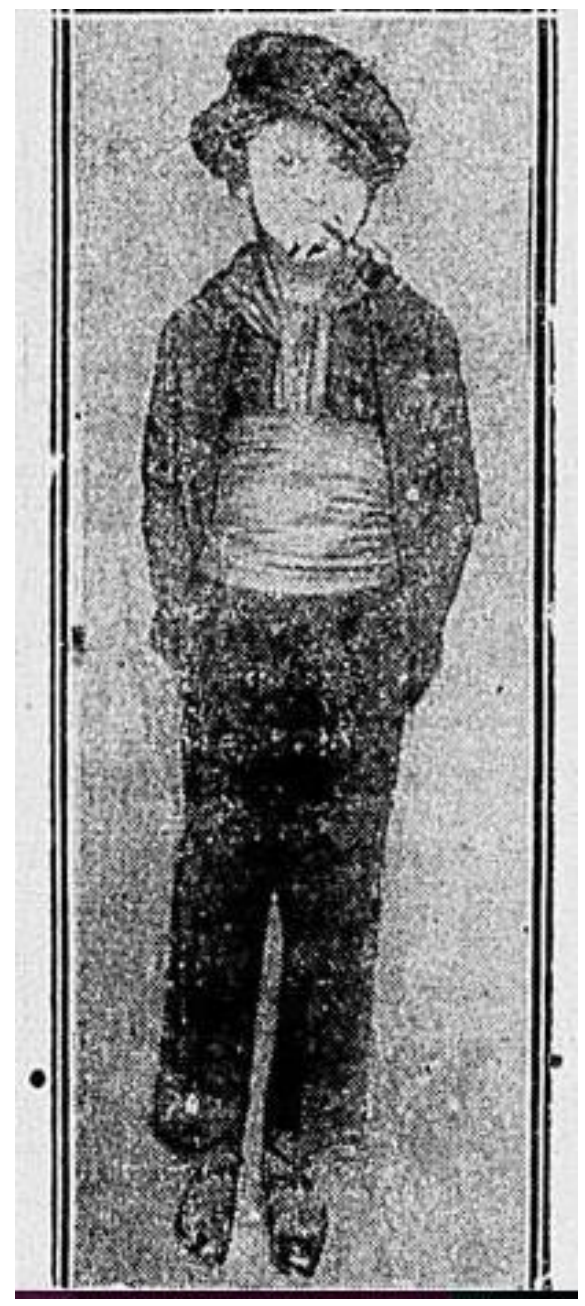

Imagem 17: A menina Irene Silva, fantasiada de apache, "o cachimbo ao canto da boca, lenço encarnado no pescoço, as mãos nos bolsos das calças, convencida de que era mesmo um apache, daqueles que constituem o terror de Paris" (Correio da Manhã, Rio de Janeiro, 16 de fevereiro, 1915).

Como explicar tal apropriação das figuras de apache e gigollete em uma manifestação cultural no Rio de Janeiro em 1915, uma vez que tais figuras eram símbolo da barbárie parisiense do início do século XX?

Algumas pistas para tal explicação podem ser encontradas a partir das matérias de jornais referentes aos bailes de carnaval, marcados pela presença das damas e cavalheiros da elite carioca fantasiados de apaches e gigolletes, como notícia do jornal Gazeta de Notícias, em 4 de fevereiro de 1915:

No populoso e aristocrático bairro de Vila Isabel, realiza-se hoje uma batalha de "confeti", que, pela animação reinante entre os seus organizadores, promete ser 
brilhantíssima (...). Os grupos dos chupetas, apaches apaixonados e o bloco dos tiriricas estão preparados para tomar parte nesta bela festa, organizada pela distinta senhorita Zaida Dias Jacaré, para solenizar a próxima chegada do Momo". ${ }^{65}$

Segundo Michelle Perrot, os apaches não eram apenas delinquentes, eles copiavam as hierarquias e gostos da sociedade que já estava estabelecida e era essa a origem de sua agressividade; expressavam uma parcela dos desejos, sonhos e recusas de uma juventude, “em confronto com as normas de uma sociedade 'áspera' que não lhes reconhece um lugar coletivo e não lhes oferece outra saída além da obediência, paciência, monotonia dos dias cinzentos". 66

O apachismo era símbolo de desestabilização da ordem, uma afronta ao que era visto como correto. Os apaches desafiavam a polícia, cometia crime de lenocínio, assaltavam e até matavam se fosse preciso.

Nos versos dos blocos carnavalesco do carnaval carioca de 1915, de forma irônica, essa mensagem era transmitida:

Eis aqui nós, os apaches
desta zona tão brejeira
viemos participar
que não somos de brincadeira.
Leva o apache
toda a farrear
vive as custa das perdidas
que vivem no Tupanar
Hoje já matamos um
por querer de nós zombar
e por isso participamos
que não somos de brincar
fazemos os nossos roubos
e também as nossas mortes
pois a polícia não se mete
porque também leva trote.

65 "Batalha de confeti", Gazeta de Notícias, Rio de Janeiro, 4 de fevereiro de 1915.

${ }^{66}$ PERROT, Michele. op.cit., p. 352.

${ }^{67}$ Bloco de Apaches do Engenho Velho, Jornal do Brasil, Rio de Janeiro, 13 de fevereiro de 1915. 


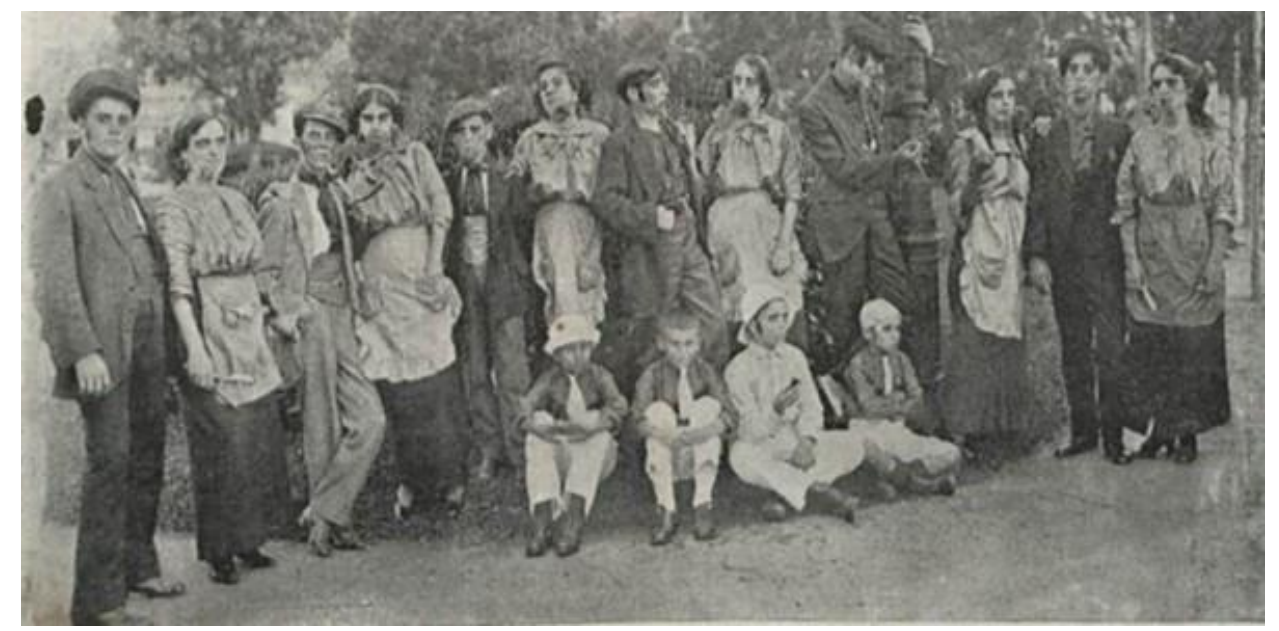

Imagem 18: Episódios da grande batalha de confetti realizada no domingo de carnaval, na Praça Sete de Março - Vila Isabel: um gracioso grupo de apaches "posando" para O Malho, e composto de empregados no comércio daquele bairro, com suas famílias ( $O$ Malho, Rio de Janeiro, 20 de fevereiro de 1915).

Para Michelle Perrot, "o fascínio que os apaches exercem sobre a juventude deve-se a força com que enfrentam a ordem estabelecida. São foras-da-lei que se orgulham de sê-lo". 68

No Rio de Janeiro, no carnaval de 1915, eles se tornaram personagens de destaque com suas gigolletes. Não foram poucos os blocos que assumiram essa caracterização: Apaches de São Cristóvão, Apaches de Paris, Apaches de Riachuelo, Apaches de S. Francisco, Apaches do Engenho Velho e Apaches Argentinos. Com suas marchinhas e fantasiados à caráter, eles transitavam livremente pela cidade durante três dias anunciando suas diabruras, zombando das leis e desafiando os policiais com suas navalhas.

As gigolletes conquistaram um espaço jamais sonhado pela mulher da época. Destemidas, provocativas, amantes, protegidas por seus apaches, se entregavam ao prazer sem pudor, causando inveja e ao mesmo tempo indignação aos que resistiam a tal liberdade.

Talvez o fenômeno apache no carnaval carioca de 1915 se explique justamente pelo fato do que representava o próprio personagem em questão: o prazer de viver uma liberdade desafiadora.

${ }^{68}$ PERROT, op. cit., p. 355. 
Dessa forma, era através das fantasias e canções que rapazes e senhoritas podiam viver essa aventura durante três dias de folia. Os blocos visitavam as redações dos jornais cantando:

\author{
Somos nós os "apaches" \\ os ladrões de Paris \\ troupe que rouba e mata \\ e que se julga feliz. \\ O mundo inteiro conhece \\ as nossas grandes façanhas, fazemos coisas incríveis, \\ fazemos coisas estranhas \\ roubamos de noite \\ roubamos em pleno dia, \\ com coragem, sem temores, com argúcia e ousadia. \\ Zombando das leis criadas \\ pelos tais policiais \\ contra eles nós trazemos \\ com coragem, sem temores, com argúcia e ousadia. \\ Zombando das leis criadas \\ pelos tais policiais \\ contra eles nós trazemos \\ bem afiados punhais. \\ Apaches somos, enfim. \\ Cavalheiros venais \\ triunfando assim \\ em todos os carnavais. ${ }^{69}$
}

\footnotetext{
${ }^{69}$ Bloco “Apaches de Paris". Correio da Manhã, Rio de Janeiro, 8 de fevereiro de 1915.
} 


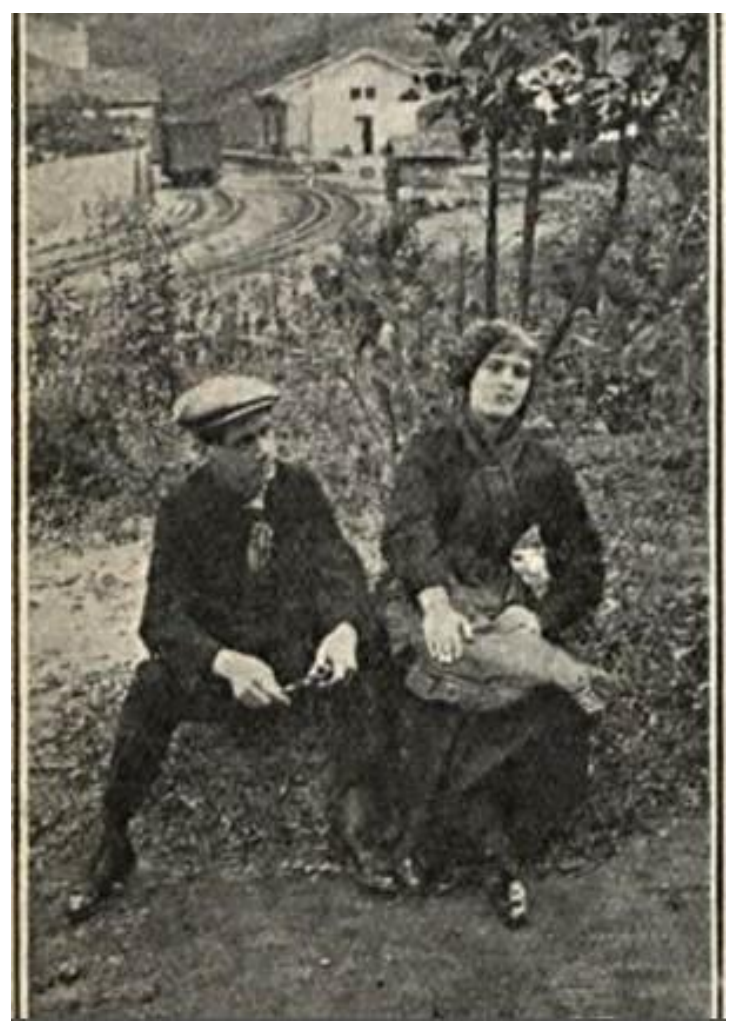

Imagem 19: Luiz Moreira e senhorita Maria Helena, filhos do Dr. Torquato Moreira, caracterizados em apaches (Fon Fon, Rio de Janeiro, 17 de abril de 1915).

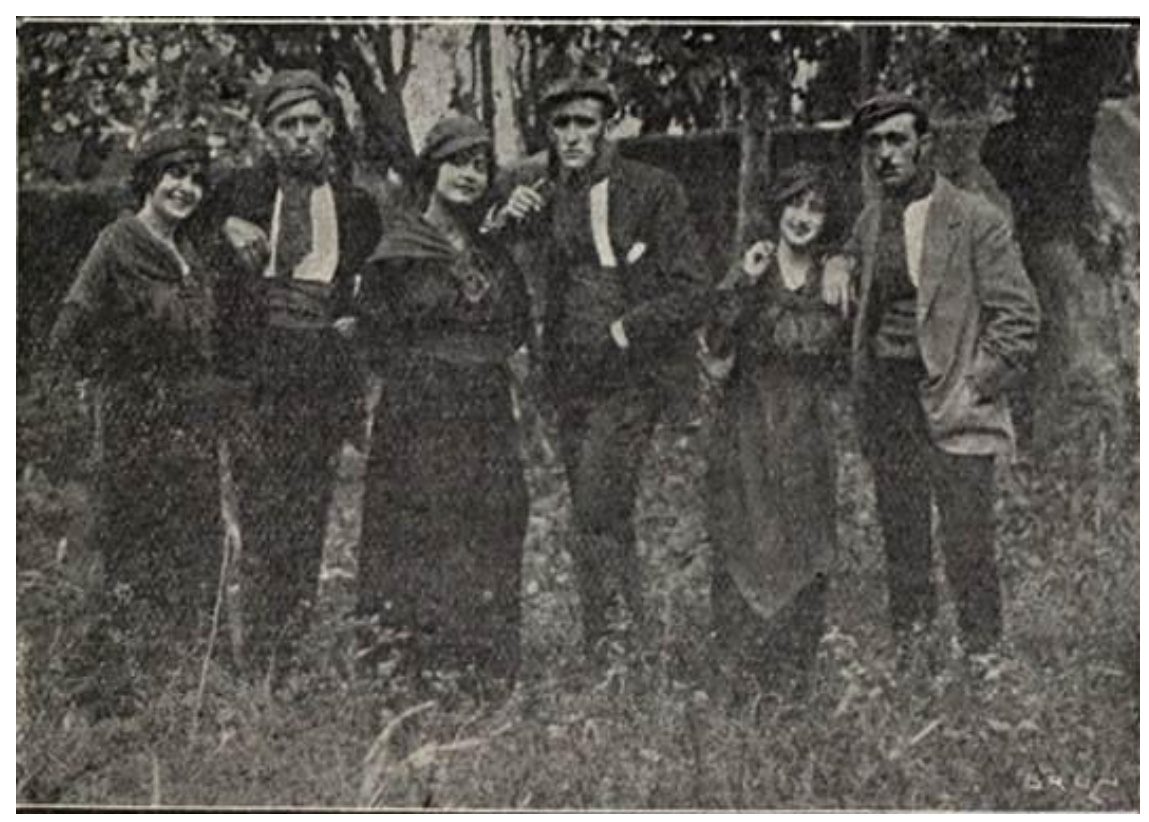

Imagem 20: "Os apaches" (da esquerda para direita): Senhorita Stella Azevedo, Sr. Militão de Carvalho, Senhorita Edith de Mattos, Sr. José Godinho, Senhorita Esther Azevedo e Dr. Jorge de Carvalho. Fon Fon, Rio de Janeiro, 28 de agosto de 1915. 


\section{Como descreve Michelle Perrot:}

O apache nasceu na calçada de Paris (...), tinha gosto pela perambulação, pelo fumo, mulheres, os prazeres do consumo e sobretudo das roupas. $\mathrm{O}$ apache gostava de estar bem-arrumado, sem ser burguês: boné de aba, baixo, redondo ou enfunado, jaqueta curta e acinturada, calça com boca larga, lenço de cores vivas, botinhas de bico fino e botões dourados. ${ }^{70}$

As mulheres eram muito solicitadas pelos apaches e, apesar de lhes prover dinheiro através da prostituição, não era esse a única razão que os unia (até porque os apaches eram proxenetas, mas não profissionais do ramo). A relação envolvia, também, segurança, afinal, elas pertenciam somente a um homem, que assumia o papel de protetor e amante, apesar de bater nelas como sinal de virilidade.

Temos, então, um o universo de crime, prostituição, mas também, amor. Aliás, na formação dos casais apaches, o amor ocupava um grande espaço. Apesar de durões, os apaches sabiam ser românticos e, de acordo com Perrot, tatuavam os nomes de suas amantes no corpo. Ao mesmo tempo, as mulheres, nesse universo, tinham uma certa liberdade de escolha e podiam trocar de homem nos casos de insatisfação. "Eram espiãs alertas e hábeis mensageiras, sabiam lutar e, ocasionalmente, manejar a navalha. ${ }^{71}$

A forma e o motivo por que as figuras de apaches e gigolletes foram apropriados na festa do Momo de 1915 no Rio de Janeiro nos permite abrir uma reflexão sobre tal festa carioca. Ao longo da pesquisa com fontes jornalísticas sobre o carnaval carioca de 1915, as fantasias de tais figuras eram usadas tanto por membros da elite carioca, como por grupos de trabalhadores, o que nos leva a crer que tal experiência envolvia uma diversidade social.

Leonardo Affonso de Miranda Pereira, em $O$ carnaval das letras, problematiza a historiografia que trabalha a partir da construção de uma memória voltada para a "existência de uma essência unívoca da folia". Dessa forma, as explicações pautadas em tal "essência unívoca da folia" acabam formulando teorias

\footnotetext{
${ }^{70}$ PERROT, op. cit., pp. 346 e 347.

71 PERROT, op. cit., pp. 349.
} 
gerais para sustentá-las e, de acordo com Leonardo Affonso de Miranda, tais teorias distanciam-se do conteúdo histórico que envolve a própria festa ao longo do tempo e em lugares diferentes, em outras palavras, desconsideram tempo e espaço. Para o autor, essas construções generalizantes para explicar o carnaval acabam por distanciar-se da verdadeira realidade das ruas, e de um estudo aprofundado sobre os “antagonismos" que marcaram as sucessivas "etapas" da história do carnaval". 72

\subsection{A questão de gênero no carnaval de 1915: a presença da mulher no espaço público}

Segundo Maria Clementina Pereira Cunha, a figura da mulher foi um ingrediente central nos préstitos e salões das sociedades desde a década de 1870. Eram as mais célebres meretrizes, algumas conhecidas como atrizes do teatro ligeiro ou artistas dos cafés-cantantes, que encarnavam as inúmeras personagens alusivas à cultura clássica (deusas, ninfas) ou as simbologias políticas dos carros montados apenas para exibi-las ao público curioso.

Mas, como acentua a autora, "o risco dessa exposição era grande: contaminar as donzelas de 'família' com a imagem de uma vida devassa e cheia de prazeres, gloriosa e alegre, distantes em todo caso das cinzentas rotinas do lar a que estavam destinadas". 73

Assim, restava para as mulheres de família o espaço privado da casa, de onde assistiam dos balcões e sacadas ao espetáculo carnavalesco. Mesmo assim, para alguns observadores moralistas, o que se podia ver parecia absolutamente degradante para os olhos de suas mulheres e filhas castas. Esse temor advinha da possibilidade de proximidade entre dois mundos femininos distintos que poderia levar ao contágio das mulheres de família.

\footnotetext{
${ }^{72}$ MIRANDA, Leonardo Affonso de, op. cit., pp. 26-27.

${ }^{73}$ CUNHA, Maria Clementina Pereira. De historiadoras, brasileiras e escandinavas. Loucuras, folias e relação de gêneros no Brasil (século XIX e início do XX). Revista tempo, Rio de Janeiro, vol. 3, n. 5, 1998, p. 23. Disponível em http://www.historia.uff.br/tempo/artigos_livres/artg5-9.pdf com acesso em 04/12/2017.
} 
$\mathrm{Na}$ virada do século, a crença de proteger a honestidade feminina por meio da honra da família era crucial para a defesa da civilização e para a construção de uma nação moderna. As autoridades trabalhavam em suas respectivas áreas (juristas, engenheiros, políticos municipais e federais, médicos sanitaristas e autoridades policiais) para evitar que as "classes perigosas" se misturassem com as famílias honestas. Com o advento da República, segundo Sueann Caulfield:

Recursos financeiros federais e municipais foram destinados a um projeto de "higienização" e "moralização" do espaço físico da cidade" (...). Ao mesmo tempo, em uma era de liberalização das normas sociais nas sociedades modernas ocidentais, a preocupação com a honra podia parecer anacrônica, ou até mesmo como apontaram alguns críticos brasileiros da época, uma indicação do atraso cultural do país. Ainda assim, a ideia de civilização simbolizava a combinação de uma modernidade cosmopolita e uma concepção patriarcal de honra e nação. ${ }^{74}$

Maria Clementina Pereira Cunha, ao tratar de três casos específicos de mulheres internadas no hospício do Juquery, em São Paulo, constata que inicialmente a perspectiva de higienização da mulher e da família se impôs como fator de diferenciação e hierarquização social, isso porque, partindo de uma representação produzida pelo olhar senhorial. "Mulatas são fêmeas, objeto de fantasia masculina (...), iaiazinhas brancas seriam futuras esposas, entes entronizados e objeto de amor casto"75, assim alguns estereótipos sociais garantiam a dominação de gênero que estava relacionada à dominação de classe.

Para além de uma prerrogativa senhorial, o objetivo de defender a família e a honra feminina passou a estar presente em várias modalidades de discursos do poder e nos preâmbulos da lei, como as modificações inscritas no Código penal de 1890 que ressalta a introdução de crimes contra a família, como lenocínio, atentado ao pudor e a corrupção de menores, que antes constavam nos capítulos relativos à injúria ou ao estupro.

Viveiro de Castro destacou-se dentre os juristas do final do século XIX e início do XX por ter se dedicado a pensar o aumento da criminalidade e nos

\footnotetext{
${ }^{74}$ CAULFIELD, Sueann. Em defesa da honra; moralidade, modernidade e nação no Rio de Janeiro (1918-1940). São Paulo: Unicamp, 2000, pp. 109-110 e 116.

${ }^{75}$ CUNHA, Maria Clementina Pereira, op. cit., p. 17.
} 
problemas que afetavam as famílias e os interesses sociais, de forma a aprofundar os seus conceitos e procedimentos jurídicos, e consequentemente como melhor aplicar as leis.

Na sua visão, os caminhos para a civilização do país estariam numa legislação eficiente que garantisse "o respeito pela honra da mulher". Ao mesmo tempo, Viveiro de Castro atribuía à própria mulher o aumento de crimes contra a sua honra (como o estupro, em primeiro lugar) porque, segundo ele, tomada por uma ideia equivocada e subversiva de emancipação, a mulher foi a responsável por perder o próprio respeito:

A antiga educação da mulher recatada e tímida, delicada, sensitiva evitando os contatos ásperos e rudes da vida, foi desprezada como coisas anacrônica e ridícula; e temos hoje a mulher moderna, vivendo nas ruas, sabendo tudo, discutindo audaciosamente as mais escabrosas questões, sem refreio religioso, ávida unicamente de luxo e sensações, vaidosa e fútil, presa fácil e muitas vezes até espontaneamente oferecida à conquista do homem. (...) a educação moderna não prepara mães de família, mulheres para viver na intimidade silenciosa do lar, e sim bonecas de salão, vaidosas e fúteis. ${ }^{76}$

Nessa perspectiva, no carnaval do Rio de 1915, ao mesmo tempo em que os jornais, em suas matérias, davam destaque aos foliões fantasiados de apaches e gigolletes, recebendo-os em suas redações, havia o repúdio de parte da sociedade ao uso dessas imagens e da presença feminina em espaços que eram concebíveis somente a homens:

E as meninas? (...) de boas famílias, adotaram o traje e, o que pior é, os ademanes das gigolettes ou mulheres de apaches no último carnaval. Imagina-se, a cinquenta anos, o efeito que em uma casa de família produziria essa lembrança de menina, aspirando a figurar pelas ruas sob o disfarce do que mais torpe e degradante se oferece nas tabernas parisienses! (...) Agora é vulgar: - Papai, deixa-me sair no carnaval de prostituta! $!^{77}$

A simbologia que a figura de gigolette representava contrastava com a imagem da mulher recatada de família que a sociedade primava em preservar. Um leitor, em carta endereçada ao redator do jornal A Noite, demonstrava em suas palavras o impacto de tais representações:

\footnotetext{
${ }^{76}$ CASTRO, Viveiros de. Os delitos contra a honra da mulher. Rio de Janeiro: Freitas Bastos, 1942, pp. 22-23.

77 “Triste, mas verdade...", Jornal do Brasil, Rio de Janeiro, 28 de fevereiro, 1915.
} 
Por intermédio do nosso conceituado jornal, na qualidade de chefe de família, peçonos a fineza de chamar a atenção das nossas patrícias para o vestuário de apache. Talvez que elas nem saibam o papel baixo e vil que representa a mulher de apache e devido a essa ignorância, é que sem dúvida se rebaixam com tal fantasia. Não creio, entretanto, que uma moça de educação, filha de uma família de sentimentos, tenha a semelhante idéia de vir para as nossas ruas caracterizadas de maneira tão esdruxula e deprimente. $^{78}$

Na segunda metade do século XIX, o conceito de família era usado para separar as mulheres simbolicamente e espacialmente dos homens e das classes trabalhadoras da cidade, ou melhor, da "massa popular".

As senhoras e senhoritas não se expunham pelas ruas, mantendo-se em espaços privados protegidos. Nesse sentido, "a família" era um termo que se referia a esse setor privilegiado que se identificava como a sociedade respeitável, mais civilizada que as massas populares. Segundo Caulfield:

A exposição em espaços urbanos cabia somente aos homens. Esse papel socialmente atribuído à mulher não era direcionado a proletárias, mulheres de rua, ex-escravas, e sim às mulheres das classes dominantes e destinado a diferenciá-las do que era considerado imoral e anti-higiênico, e que estava bem distante do que a "boa" sociedade criava para si e tentava proteger com barreiras higiênicas e profiláticas. ${ }^{79}$

A historiadora Martha de Abreu acentua que a classe trabalhadora formava uma cultura relativamente autônoma e isso se dava, essencialmente, devido a práticas cotidianas bastante particulares. "Toda política de controle e repressão, atualizada pela República, no Rio de Janeiro, comprova a ameaça que representava essa autonomia". ${ }^{80}$

No caso das mulheres, algumas podiam ser vistas como desordeiras por não estarem de acordo com a moralidade aceita pela sociedade vigente. Elas "eram as construtoras da diversidade", como acrescenta Martha Abreu. A este grupo, pertenciam as mulheres negras, pobres e operárias, que experimentavam de forma

\footnotetext{
78 "O que diz um leitor - Os apaches", A Noite, 15 de fevereiro, Rio de Janeiro, 1915.

${ }^{79}$ CAULFIELD, Sueann, op. cit., pp.119-120.

${ }^{80}$ ESTEVES, Martha de Abreu. Meninas Perdidas: os populares e o cotidiano do amor no Rio de Janeiro da Belle Époque. Rio de Janeiro: Paz e Terra, 1989, p.121.
} 
distinta os valores morais, concepções de honra, virgindade e casamento, entrando em contradição com o que os juristas da época pretendiam afirmar.

No decorrer da segunda metade do século XIX, um grupo de profissionais como juristas e sanitaristas já trabalhava na implantação de medidas de moralidade e saúde pública que tinham o objetivo de higienizar o centro da cidade. Essas políticas atuavam em nome da "higiene social" e saúde pública, em campanhas que regulamentavam o carnaval e outras atividades públicas de lazer, e nas tentativas de punir os crimes sexuais e de controlar a prostituição, visando principalmente por fim a uma "mistura promíscua", ou seja, segregando o espaço público do privado.

Nessa perspectiva, o gênero era fundamental nas concepções brasileiras sobre espaço privado e público. A ideologia das autoridades médicas e psiquiátricas que sustentava a tentativa de sanear e modernizar as famílias burguesas do Rio de Janeiro no início do século XX acabou por se aproximar da definição de família determinada por juristas na legislação imperial e republicana: “as mulheres eram naturalmente feitas para a vida doméstica, na qual constituía a força moralizadora. O espaço público era domínio dos homens, mais agressivo por natureza". ${ }^{81}$ Segundo Marta de Abreu Esteves:

A rua no início do século $\mathrm{XX}$ ainda era pouco visitada pela mulher, desde criança, essa mulher tinha o lazer condicionado ao espaço único da casa em que morava. $\mathrm{O}$ horário, em companhia de quem e o destino eram as grandes referências de honestidade que recaíam sobre a mulher". ${ }^{82}$

No que se refere à figura da gigollete apropriada pelas mulheres da sociedade carioca no carnaval de 1915, esta não está relacionada somente à imagem da mulher que se expõe em espaços públicos, mas também relacionada ao que a própria figura em si representava. Vale ressaltar que a gigollete era amante e ao mesmo tempo aliciada pelo companheiro apache, dessa forma o peso do meretrício também era associado à sua imagem.

\footnotetext{
${ }^{81}$ CAULFIELD, Sueann, op. cit., pp. 119-120.

${ }^{82}$ ESTEVES, Marta de Abreu, op. cit., p.43.
} 
Como destaca Martha de Abreu, "a prostituição não envolvia só a frequência sexual, mas um determinado comportamento, como andar só, fantasiar-se e sair à noite, e até pensamentos, como a intenção de não voltar para dormir em casa". 83

Ao mesmo tempo, as prostitutas contribuíram na formação tanto da imagem negativa quanto da imagem positiva da sensualidade tropical do Rio de Janeiro durante o século XIX. Isso porque havia uma dualidade entre as escravas que eram forçadas pelos seus senhores a se prostituírem, reforçando a imagem de um Rio de Janeiro corrompido pela escravidão, e as prostitutas europeias de alta classe, principalmente as coquetes francesas, que atendiam os homens de alta classe, que recebiam delas além de seus serviços, lições de boas maneiras e hábitos cosmopolitas.

No entanto, as autoridades públicas recomendavam algum tipo de controle em relação à prostituição, no sentido de se estabelecer zonas específicas da cidade para a localização das prostitutas, com o objetivo de evitar o contato entre as mulheres "públicas” e as de família.

Com a reforma empreendida pelo prefeito do Rio de Janeiro, Pereira Passos, no início do século XX, entre 1903 e 1906, envolvendo o tão comentado "bota abaixo" (que demoliu os cortiços e expulsou os pobres do centro da cidade), aos poucos, as áreas correspondentes foram embelezadas e ocupadas por um seleto conjunto de estabelecimentos comerciais, culturais e sociais para atender a elite carioca.

O passo seguinte seria manter tais áreas moralizadas, sem prostitutas, vadios e quaisquer outros cuja presença significasse um desaforo para a honra de mulheres burguesas que passaram a frequentar esses espaços públicos. O que seguiu foram políticas policiais que delimitavam tais espaços - geralmente destinados ao lazer masculino - à frequência de apenas alguns tipos de mulher, que pudessem satisfazer os instintos masculinos sem ofender, tampouco atrair mulheres honestas e de família, ou seja, era uma medida para evitar a contaminação do tecido social e preservar os valores familiares.

\footnotetext{
${ }^{83}$ Idem, p.52.
} 
Contudo, no período entreguerras, a concepção de que os homens tinham passe livre nos espaços públicos (seja para trabalhar ou se divertir), enquanto as senhoras de família ficavam em casa foi mudando na medida em que as mulheres de projeção das classes média e alta passaram a rejeitar os limites conceituais que as excluíam do espaço público. Segundo Caulfield:

Essa mudança ganhou força com os movimentos feministas encabeçados pelas mulheres de classe média, por meio de revistas femininas ou de pequenas organizações feministas, como a Federação Brasileira para o Progresso Feminino, que faziam lobby com políticos a fim de conseguir direitos iguais de propriedade, acesso à educação e direito a voto. Com isso, muitas mulheres das classes média e alta passaram a ocupar fisicamente áreas cada vez maiores do espaço público, somando-se aos homens no trabalho e no lazer. Posteriormente, na década de 1920, os espaços impróprios, como os bordéis de "baixo nível" de Copacabana, onde mulheres "honestas" não circulavam, deram lugar a espaços claros e saudáveis, permitindo que essas mulheres se misturem aos homens. ${ }^{84}$

Essa mudança de paradigmas e de comportamento se deu principalmente pelo fato de haver uma propaganda massiva de exportação cultural dos Estados Unidos, representada principalmente através de filmes, em que a imagem de uma nova mulher decidida e independente despontava.

Para a escritora Gilka Machado, "a mudança nos papéis de gênero e o aumento da liberdade sexual das mulheres eram sinais de progresso, demonstrando o avanço das sociedades supostamente civilizadas" ${ }^{\circ 5}$, no entanto, o grupo mais conservador da sociedade entendia que a liberdade sexual feminina era uma indicação de que a desordem e o vício, típicos das massas populares, haviam vencido o refinamento civilizado das elites.

Apesar do discurso moralizador que envolvia um saneamento social e espacial como forma de preservar os valores resguardados por uma sociedade ancorada em uma herança patriarcal, aos poucos, como a própria historiografia mostra, tanto homens como mulheres passaram a compartilhar espaços que antes eram negados às mulheres da "boa" sociedade. Apesar de alguns anos antes a presença de mulheres no

\footnotetext{
${ }^{84}$ CAULFIELD, Sueann, op. cit., p. 139.

${ }^{85}$ MACHADO, Gilka apud CAULFIELD, Sueann, op. cit.,pp. 140-141.
} 
carnaval carioca, fantasiadas de gigolletes ao lado de apaches, parecesse algo escandaloso, o que se percebe através das notícias dos jornais da época é que não eram poucos os blocos e canções alusivas às imagens de apaches e gigolletes.

Mesmo com a indignação de parte da sociedade, eram em momentos como o carnaval que as liberdades de se expressar e de se comportar de determinada forma eram amplamente exercidas. A caracterização de apaches e gigolletes por homens e mulheres e a aparição dos blocos e suas canções durante três dias de folia rompiam com as barreiras tanto ideológica como geográfica que eram impostas em nome da honra da família. Ao mesmo tempo, a possibilidade de um novo debate envolvendo relações de gênero emergia a partir da irreverência que tais representações podiam suscitar.

É curioso pensar que em uma sociedade em que era tão discutido questões como a honra da mulher associado aos valores da família, essas representações haviam ganhado tanto espaço. Ao mesmo tempo tais aparições podem sinalizar um movimento no sentido de repensar o papel e o significado da mulher na sociedade de uma forma diferente das defendidas pelas autoridades da época, que buscavam meios legais de manter uma segregação entre mulheres negras, pobres e operárias das consideradas de família e castas, como forma de garantir valores morais.

A aparição das imagens de apaches e gigolletes nas fantasias no carnaval carioca de 1915 pode ter sido um indício de rompimento de barreiras em uma sociedade marcada por valores morais e questões de gênero. Mais do que rompimento de barreiras, pode ter sido um indício de como essas fronteiras estavam sendo negociadas e eram objeto de disputas. 


\section{Conclusão}

Este trabalho analisou o "fenômeno do apachismo" e suas particularidades, desde o seu nascimento, em Paris, até sua chegada e influência no espaço Atlânticosul-americano. Mas, na minha opinião, o mais fascinante das pesquisas são as descobertas que fazemos e as perguntas que ficam para serem respondidas, pois a pesquisa não se esgota. Esse tema me provocou exatamente isso: descobertas e indagações. O apachismo, como tentei mostrar ao longo deste trabalho, foi uma construção, uma invenção e ao mesmo tempo teve uma presença concreta, no tempo e em determinados espaços. Isso porque a imprensa, a literatura e os próprios criminosos apropriaram-se de formas distintas do termo.

De início vimos como Michelle Perrot problematiza a origem do termo apache, que pode ter sido uma construção dos principais jornais da época, ou dos próprios policiais indignados com os crimes dos ditos apaches, ou a apropriação do termo teria partido dos próprios jovens delinquentes, que tinham o costume de se batizarem com nomes coletivos. No entanto, as múltiplas possibilidades de apropriação não se reduzem a encontrar uma paternidade para o termo.

Dominique Kalifa amplia o aspecto social do "fenômeno apache" ao analisar a sua apropriação pelo cinema, pela música e pela literatura folhetinesca, a partir de uma perspectiva cultural. Dessa forma podemos entender tal fenômeno a partir de um duplo sentido: o cultural, ao pensar as representações que o apachismo suscitou, e o social como produção, isto é, o que a sociedade produz de si própria.

Os apaches, como vimos, eram representados por uma parcela da juventude parisiense considerada como os últimos rebeldes que contestavam as contradições de seu tempo, eram os desclassificados. Ao perderem o seu estatuto social, tiveram que se reinventar. Aos poucos o aumento dos índices de criminalidade entre as faixas etárias de 16 e 21 anos alarmaram as autoridades. Mas o que fazer com esse grupo, visto como uma horda de delinquentes? Nascia o debate em torno dos castigos físicos como forma de extirpar, através do medo, esse mal social. Concomitantemente, o cerco policial se intensificava e o apache humilhado e perseguido tentava escapar e 
sobreviver em outras bandas. Ainda assim, terror e inspiração eram características latentes desses personagens por onde quer que passassem.

Em consequência disto, vimos o efeito da "diáspora apache" em outras localidades, desencadeando uma conjuntura de repressão policial por onde passaram na Europa, Barcelona; na América do Sul, envolvendo cidades como Buenos Aires, Montevidéu e Rio de Janeiro.

Em face disto, os jornais da época dinamizaram as informações referentes aos apaches, dando destaque principalmente à expulsão de indivíduos acusados de apachismo em solo argentino e à passagem pelos mesmos nos portos do Rio de Janeiro e Montevidéu.

Ao mesmo tempo, as fontes jornalísticas analisadas nos permite pensar nas várias faces que o apachismo ganhou a partir da imprensa. E para entender esse aspecto direcionei o foco para a centralidade que a imprensa francesa ocupava na época, o nascimento de uma nova modalidade narrativa, o romance judiciário, e o espaço que as narrativas de crime ganharam nos periódicos sob a forma de notícias. $\mathrm{O}$ objetivo era impressionar o leitor e causar "sensação".

Mas invenção (ou criação) no universo midiático não está dissociado das práticas sociais. Os principais jornais da época publicavam diariamente a perseguição movida pelas autoridades policiais de Buenos Aires e Rio de Janeiro na repressão contra imigrantes franceses acusados de apachismo. Muitos deles foram perseguidos, expulsos e deportados para seus países de origem. A notícia do Correio da Manhã intitulada "O último bando", como já foi citada, apresenta uma relação de cento e vinte nomes de pessoas suspeitas de apachismo que passaram pelo porto do Rio de Janeiro e foram deportadas para Europa. Mas o fenômeno apache permaneceu no imaginário da sociedade inspirando as manifestações culturais da época. No Rio de Janeiro, as figuras de apaches e gigollettes deram o tom da festa do Momo de 1915. Tal fenômeno foi revivido por homens e mulheres da sociedade nas fantasias, na formação dos blocos carnavalescos como Apaches de São Cristóvão, Apaches de Paris, Apaches de Engenho Velho e Apaches Argentinos. 
As mulheres, fantasiadas de gigollettes, percorreram espaços que lhes eram negados, ganharam as ruas. Destemidas, provocativas, amantes, protegidas por seus apaches, se entregam ao prazer sem pudor, desencadeando o debate sobre a questão da honra da mulher e da família na sociedade.

Nesse contexto, como explicar a apropriação das imagens de tal fenômeno pela sociedade carioca no carnaval de 1915? Talvez pelo que o próprio personagem representa: o prazer de viver uma liberdade desafiadora, ou como Dominique Kalifa destaca, grupos populares sentem-se atraídos por desobediências e delitos, por rompimentos sociais, e os jornais de grande tiragem conseguem resgatar esse imaginário. Isso porque, histórias de crime contam aos leitores elementos de suas próprias vidas e histórias. Já, segundo Michelle Perrot, ao analisar o papel do jovem transgressor de Paris do início do século XX, o descreve como um contestador da ordem estabelecida, do século em que vivia e suas contradições.

Acredito que ambos os autores apresentam argumentos sólidos para entendermos o fenômeno apache não só na esfera do crime, ou seja, social, mas na esfera cultural, a partir das representações que ele mobilizou. Mas ainda assim, o tema dos apaches parisienses deixa brechas para podermos continuar pensando no seu poder de sedução que inspirou vários atores sociais de sua época, afinal, como já disse, uma pesquisa nunca se esgota. 


\section{Fontes}

O telegrama apresentado nesta monografia faz parte do acervo do Arquivo Nacional. As crônicas citadas ao longo do trabalho estão disponíveis no Banco de

dados da Biblioteca Nacional - Hemeroteca Digital e podem ser acessadas através do link: http://bndigital.bn.gov.br/hemeroteca-digital.

O Paiz, 21 de dezembro de 1910

O Paiz, 24 de dezembro de 1910

O Paiz, 13 de fevereiro de 1910

O Paiz, 25 de agosto de 1910

O Paiz, 16 de setembro de 1910

Correio Paulistano, 24 de outubro de 1910

O Imparcial, 19 de outubro de 1913

Fon Fon, 5 de agosto de 1916

Fon Fon, 26 de outubro de 1912

Correio da Manhã, 20 de maio de 1913

Correio da Manhã, 11 de maio de 1910

Correio da Manhã, 27 de setembro de 1911

Correio da Manhã, 15 de setembro de 191

O Malho, 9 de maio de 1914

Correio da Manhã, 16 de setembro de 1912

Correio da Manhã, 17 de outubro de 1912

Correio da Manhã, 27 de setembro de 1912 
A Pacotilha, 30 de setembro de 1911

Correio da Manhã, 12 de setembro de 1913

Gazeta de Notícias, 16 de fevereiro de 1916

Correio da Manhã, 15 de janeiro de 1915

Correio da Manhã, 11 de fevereiro de 1915

Fon Fon, 20 de março de 1915

Fon Fon, 10 de agosto de 1912

Correio da Manhã, 24 de outubro de 1913

Correio da Manhã, 14 de fevereiro de 1915

O Malho, 11 de março de 1916

Correio da Manhã, $1^{\circ}$ de fevereiro de 1915

Correio da Manhã, 16 de fevereiro de 1915

O Paiz, 16 de fevereiro de 1915

A Época, 17 de fevereiro de 1915

Gazeta de Notícias, 4 de fevereiro de 1915

Jornal do Brasil, 13 de fevereiro de 1915

O Malho, 20 de fevereiro de 1915

Correio da Manhã, 8 de fevereiro de 1915

Fon Fon, 17 de abril de 1915

Fon Fon, 28 de agosto de 1915

Jornal do Brasil, 28 de fevereiro de 1915

A Noite, 15 de fevereiro de 1915 


\section{Bibliografia}

CASTRO, Viveiros de. Os delitos contra a honra da mulher. Rio de Janeiro: Freitas Bastos, 1942.

CAULFIELD, Sueann. Em defesa da honra; moralidade, modernidade e nação no Rio de Janeiro (1918-1940). São Paulo: Unicamp, 2000.

CUNHA, Maria Clementina Pereira. Ecos da Folia: uma história social do carnaval carioca entre 1880 e 1920. São Paulo: Companhia das Letras, 2001.

. De historiadoras, brasileiras e escandinavas. Loucuras, folias e relações de gênero no Brasil (século XIX e início do XX). Tempo, rio de Janeiro, Vol. 3, nº 5, 1998.

Disponível em http://www.historia.uff.br/tempo/artigos_livres/artg5-9.pdf com acesso em 04/12/2017.

ESTEVES, Martha de Abreu. Meninas Perdidas: os populares e o cotidiano do amor no Rio de Janeiro da Belle Époque. Rio de Janeiro: Paz e Terra, 1989.

GALEANO, Diego. Criminosos Viajantes. Circulações transacionais entre Rio de Janeiro e Buenos Aires (1890-1930). Rio de Janeiro: Arquivo Nacional, 2016.

HOZ, Raúl Gimero de lo. Apaches. In: Hampa, Anarquistas, Bandoleiros e Apaches. Los bajos fondos en Españha (1900-1923). Madrid: La Felguera Editores, 2016.

KALIFA, Dominique. Arqueologia do "Apachismo": Bárbaros e Peles-vermelhas no século XIX. Projeto História, nº40, 2010, p.40. 
LAGENEST, H. D. Barruel de. Lenocínio e prostituição no Brasil. Rio de Janeiro: Agir, 1960.

O’DONNELL, Julia. De olho na rua. A cidade de João do Rio. Rio de Janeiro: Zahar, 2008.

PEREIRA, Leonardo Affonso de Miranda. O carnaval das letra. Literatura e folia no Rio de Janeiro do século XIX. São Paulo: UNICAMP, 2004.

PERROT, Michelle. Na França da Belle époque, os "apaches", primeiros bandos de jovens. In: Os excluídos da História. Operários, mulheres e prisioneiros. São Paulo: Paz e Terra, 2017.

PORTO, Ana. Gaboriau e o romance judiciário no Brasil. XXVII Simpósio Nacional de História, Natal, 20013.

RIO, João do. A alma encantadora das ruas: crônicas. São Paulo: Companhia das Letras, 2008. 